\title{
Effect of supercooling on the storage stability of rapidly frozen-thawed pork loins
}

\author{
Eun Ji Choi ${ }^{1}$, Hae Woong Park ${ }^{1}$, Young Bae Chung ${ }^{1}$, Jin Se Kim², \\ Seok Ho Park ${ }^{2}$, Ho Hyun Chun ${ }^{1 *}$ \\ ${ }^{1}$ Advanced Process Technology and Fermentation Research Group, World Institute of Kimchi, Gwangju 61755, Korea \\ ${ }^{2}$ Postharvest Engineering Division, National Academy of Agricultural Science, RDA, Wanju 55365, Korea
}

\section{과냉각 온도가 급속냉동해동 처리된 돈육 등심의 저장성에 미치는 영향}

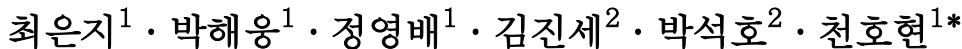 \\ ${ }^{1}$ 세계김치연구소 신공정발효연구단, ${ }^{2}$ 농촌진흥청 국립농업과학원 수확후관리공학과
}

\begin{abstract}
This study was performed to determine the rapid thawing method for reducing the thawing time of frozen pork loins and to examine the effects of supercooling on the microbiological, physicochemical, and sensory qualities of fresh and frozen-thawed pork during storage at $-1.5,4$, and $15^{\circ} \mathrm{C}$. Forced-air thawing at $4{ }^{\circ} \mathrm{C}$ was the most time-consuming process, whereas radio frequency thawing time was the shortest by dielectric heating. The supercooling storage temperature was chosen to be $-1.5^{\circ} \mathrm{C}$ because microstructural damages were not observed in the pork sample after cooling at $-1.5^{\circ} \mathrm{C}$ for $24 \mathrm{~h}$. Fresh or frozen-thawed pork loins stored at $-1.5^{\circ} \mathrm{C}$ had lower drip loss and total volatile base nitrogen, thiobarbituric acid-reactive substance, and Hunter $b^{*}$ levels than loins stored at 4 and $15^{\circ} \mathrm{C}$. In addition, the least degree of increase in preexisting microorganisms counts of the fresh or frozen-thawed pork loin samples was obtained during supercooled storage at $-1.5^{\circ} \mathrm{C}$. Sensory quality results of fresh and frozen-thawed pork loin samples stored at $-1.5^{\circ} \mathrm{C}$ showed higher scores than the samples stored at 4 and $15^{\circ} \mathrm{C}$. These data indicate that supercooling at $-1.5^{\circ} \mathrm{C}$ in the meat processing industry would be effective for maintaining the quality of pork meats without ice crystal nucleation and formation.
\end{abstract}

Key words : supercooling, storage, pork loin, quality, thawing

\section{서 론}

2015년 농림축산식품 주요통계에 따르면 국민 1인당 돈 육 소비량은 $20.9 \mathrm{~kg}$ 으로 국산 축산물 중 가장 높은 소비량 을 차지하고 있다(1). 돈육은 안심, 등심, 목심, 전지, 후지, 삼겹살과 갈비살의 총 7 개 부위로 대분할하여 부분육으로 유통하는데 이 중 삼겹살과 목심은 도체 중량에 대한 생산 수율이 약 $30 \%$ 정도에 불과하지만 소비자 선호가 높아

*Corresponding author. E-mail : hhchun@wikim.re.kr Phone : 82-62-610-1761, Fax : 82-62-610-1850

Received 15 February 2017; Revised 28 March 2017; Accepted 28 March 2017.

Copyright (c) The Korean Society of Food Preservation. All rights reserved.
신선 냉장육 상태로 판매 소진되고 있다(1,2). 한편 등심은 비선호 부위로 생산량에 비해 소비량이 적어 장기간 보관 목적으로 동결 처리하는데 저지방과 균일한 육질 특성을 갖고 있어 주로 식육 가공식품의 원료육으로 이용하고 있다 (3).

돈육의 품질은 미생물 오염도, 색도, 보수력, $\mathrm{pH}$ 등에 의해 결정되며 이러한 요인들은 돈육의 제품수명과 가공적 성에 영향을 미친다(4). 특히, 신선육에 비해 냉동-해동 처 리된 돈육은 저장 중 드립감량 증가와 빠른 미생물 증식에 의한 품질 저하가 쉽게 발생하며 식육 가공품 제조 시 품질 과도 직결되기 때문에 돈육의 효과적인 냉동 및 해동처리와 저장기술 적용이 필요하다(5). 일 반적으로 $-18-30^{\circ} \mathrm{C}$ 송풍 식 냉동고에서 식품을 동결하는 완만 냉동은 냉동 속도가 느려 육류 내 얼음결정이 근섬유 내부보다 외부에 형성된 
다. 그 결과 얼음결정에 의한 부피 증가로 조직이 물리적 손상을 입고 파괴되어 해동이나 저온 저장 시 과다 드립유 출, 보수력 감소 등이 발생할 우려가 있다(6). 이러한 문제점 을 개선하기 위한 냉동기술 중 액체 침지식 냉동은 초저온 에탄올 또는 액체질소를 이용하여 육류 급속 동결시키는 방법으로 최대빙결정형성대를 통과하는 시간이 매우 짧아 단백질 동결 변성이 적고 육류 내 형성되는 얼음결정 크기 가 매우 작아 조직손상 발생을 최소화할 수 있다(7).

냉동육을 이용한 식육 가공식품 제조 시 해동과정은 필 수적이다(8). 신선육을 동결시키기 위해서는 반드시 냉동 장비가 필요하지만 냉동육의 해동은 해동 장비의 사용 없이 물 또는 공기만으로 가능하기 때문에 해동기술 개발에 대한 중요성은 충분히 인식되지 못하였다(8,9). 전통적인 완만 해동 방법으로 유수식 해 동, 냉장 해동 또는 열풍 해동이 있지만 장시간 해동, 육표면 산화, 표면 과열, 미생물 교차오 염 등의 문제점이 발생한다(10). 따라서 산업체에서 적절한 해동은 냉동육의 품질에 큰 영향을 미치며 폐기 손실 감소, 야간작업 감소 등 경제적인 면에도 직접적인 관계가 있다 (11).

전자기파는 파장에 따라 자외선, 적외선, 마이크로파, 라 디오파 등으로 구분되는데 전자기파의 전기장이 양과 음으 로 진동할 때 유전체 내부에 극성을 가진 물분자가 양과 음을 바꾸어 빠르게 회전하고 충돌하는데 이러한 운동에너 지가 열에너지로 바뀌는 원리로 유전체의 온도를 높인다 (12). 특히 마이크로파 $300 \mathrm{MHz}-300 \mathrm{GHz}$ 범위 중 통신용으 로 사용하지 않는 $2,450 \mathrm{MHz}$ 마이크로파 해동은 전통적인 해동 방법에 비해 해동 시간을 단축할 수 있는 장점이 있지 만 해동 시 침투깊이가 낮아 부분 가열 현상이 나타난다 (13). 반면 13.56 또는 $27.12 \mathrm{MHz}$ 의 낮은 주파수의 라디오파 해동은 dielectric heating을 이용하는 면에서 마이크로파 해 동방법과 유사하지만 라디오파 해동은 냉동육에 침투깊이 가 높아 균일한 해동이 가능한 장점이 있다(14).

한편 식품의약품안전처에서 고시한 축산물의 가공기준 및 성분규격은 냉동육의 해동 후 재냉동을 금지하고 있기 때문에 일단 해동된 경우 해동육을 올바르게 관리해야 한다 (15). 국내의 경우 육제품 냉장은 $0-10^{\circ} \mathrm{C}$ 에서 보관되도록 온도관리를 규정하고 있지만 냉장온도의 범위가 넓어 유통 매장에서 온도관리가 어려운 실정이다(16).

식품동결 이론에 따르면 과냉각은 물질의 상전이 온도 이하로 냉각하여도 빙결정 형성 없이 원래의 상을 유지하고 있는 불안정한 상태로 식품의 구성성분 및 초기온도, 포장 형태, 저장고 온도변화에 따라 과냉각 상태를 유지하는 정 도는 다양하다. 국외에서 공랭식, 아이스 슬러리, 냉각 염수 또는 냉각 에탄올 침지식 방법으로 동결점에 근접한 상태로 저장하는 과냉각 기술을 이용하여 농축수산물의 품질유지 기한 연장 연구가 활발히 수행되고 있다(17). 2016년 미국 에서 펄스전기장과 진동자기장을 이용하여 계육 가슴살의
과냉각 온도구간을 연장시킨 결과가 보고되었다(18). 또한 2012년 일본에서 방어, 넙치와 도미를 $-3.5-5^{\circ} \mathrm{C}$ 부근까지 동결발생 없이 저장할 수 있다는 결과가 발표되었다(19). 국내에서는 육류의 저장성 향상을 위한 자외선 조사(20), 유기산 처리(4) 또는 냉동 저장(21) 연구가 수행된 바 있지 만 과냉각 온도구간에 저장한 돈육의 품질유지 연장 연구는 수행된 바 없다.

따라서 본 연구는 초저온 액체 침지식 냉동으로 급속 동결된 돈육 등심을 라디오파 급속 해동 처리하고 과냉각 저장 중 미생물학적 및 이화학적 품질, 미세구조를 분석하 여 과냉각 저장기술에 대한 효과를 알아보고자 하였다.

\section{재료 및 방법}

\section{실험재료}

본 실험에 사용한 돈육은 돼지를 도축 후 약 24 시간 동안 냉장된 상태의 등심(Longissimus thoracis et lumborum) 부위 를 광주 소재 전문 식육점에서 구입하였다. 멸균된 칼을 이용하여 돈육 등심에 결체조직과 지방조직을 제거한 후 $100 \times 100 \times 70 \mathrm{~mm}$ 크기로 정형하여 시료를 준비하였다.

\section{초저온 액체 침지식 급속 냉동}

돈육 시료를 polyethylene film bag에 넣은 후 진공포장기 (FR-B100WB, CSE Co., Siheung, Korea)를 이용하여 개별적 으로 진공포장 하였다. 시료를 $95 \%$ 에탄올과 $5 \%$ 불소로 구성된 coolant와 jet agitation regulator가 갖춰진 액체 침지 식 급속 냉동기(F-500, Top Greentech Co., Seoul, Korea)를 이용하여 $-70^{\circ} \mathrm{C}$ 를 유지한 coolant에 약 20 분간 침지하여 급속 동결하였다. 급속 동결 후 돈육 시료는 $-20^{\circ} \mathrm{C}$ 냉동 저장고에서 해동 시까지 보관하였다.

\section{냉동 돈육의 급속 해동방법 선정}

냉동 돈육의 급속 해동방법을 선정하기 위해 강제 송풍 식 해동, 유수식 해동과 라디오파 해동을 이용하여 해동속 도를 분석하였다. 강제 송풍식 해동은 4 와 $10^{\circ} \mathrm{C}$ 로 설정된 항온항습기(송풍속도 1.2-1.5 m/s, SH-202M, Human Corporation, Seoul, Korea)를 이용하여 처리하였다. 유수식 해동은 수온이 4 와 $10^{\circ} \mathrm{C}$ 로 유지된 water bath(VS-1205SW1, Vision Scientific Co., Bucheon, Korea)에서 처리하였다. 라 디오파 해동은 $27.12 \mathrm{MHz}$ 라디오파 해동기(FRT-5, Yamamoto Vinita Corp., Ltd., Osaka, Japan)를 이용하여 시료와 상부 electrode의 간격을 $30 \mathrm{~mm}$ 로 설정하고 $400 \mathrm{~W}$ 출력에서 시료를 처리하였다(Fig. 1). 시료의 중심부에 강제 송풍식과 유수식 해동은 button temperature logger(SL52T, Signatrol Ltd., Tewkesbury, UK)를, 라디오파 해동은 fiber optic temperature sensor(FOTEMP4, Optocon AG, Dresden, 
Germany)를 각각 삽입하고 중심부 온도가 $0^{\circ} \mathrm{C}$ 에 도달하는 때를 해동완료 시점으로 하였다(Fig. 1).

\section{냉각온도에 따른 돈육의 미세구조 변화}

돈육의 과냉각 저장온도를 결정하기 위해 시료를 $-1.5 \pm 0.5,-2.5 \pm 0.5,-3.5 \pm 0.5$ 와 $-5 \pm 0.5^{\circ} \mathrm{C}$ 에서 각각 24 시간 냉각 후 시료의 표면과 중심부를 채취하여 냉각처리 전 시료의 미세구조와 비교하였다. 돈육 조직의 미세구조 관 찰을 위해 돈육을 근섬유 배열의 직각방향과 $10 \mathrm{~mm} \times 10$ $\mathrm{mm}$ 크기로 세절하고 $10 \%$ 포르말린 용액에 48시간 고정한 후 파라핀 블록을 제작하였다. 파라핀 블록은 ultramicrotome (Leica RM2255, Leica Co., Wetzlar, Germany)을 이용하여
$4 \mu \mathrm{m}$ 로 박절 후 슬라이드에 부착하였다. Hematoxylin \& Eosin 자동 염색장치(Tissue-TeK Prisma E2, Sakura Finetek USA Inc., Torrance, CA, USA)을 이용하여 탈파라핀화, 함 수, 수세, 청색화, 탈수 및 투명화 과정으로 세포질을 염색하 였다. 이후 Canada balsam으로 봉입하고 광학현미경 (Pannoramic MIDI, 3DHISTECH Ltd., Budapest, Hungary) 으로 검경하였다.

\section{해동 돈육의 저장}

초저온 액체 침지식 급속 냉동과 라디오파 급속 해동 처리된 돈육 시료는 플라스틱 사각 용기 $(130 \times 950 \times 550 \mathrm{~mm})$ 에 저장 일수에 따라 개별적으로 포장한 후 과냉각 $\left(-1.5^{\circ} \mathrm{C}\right)$,

(a)

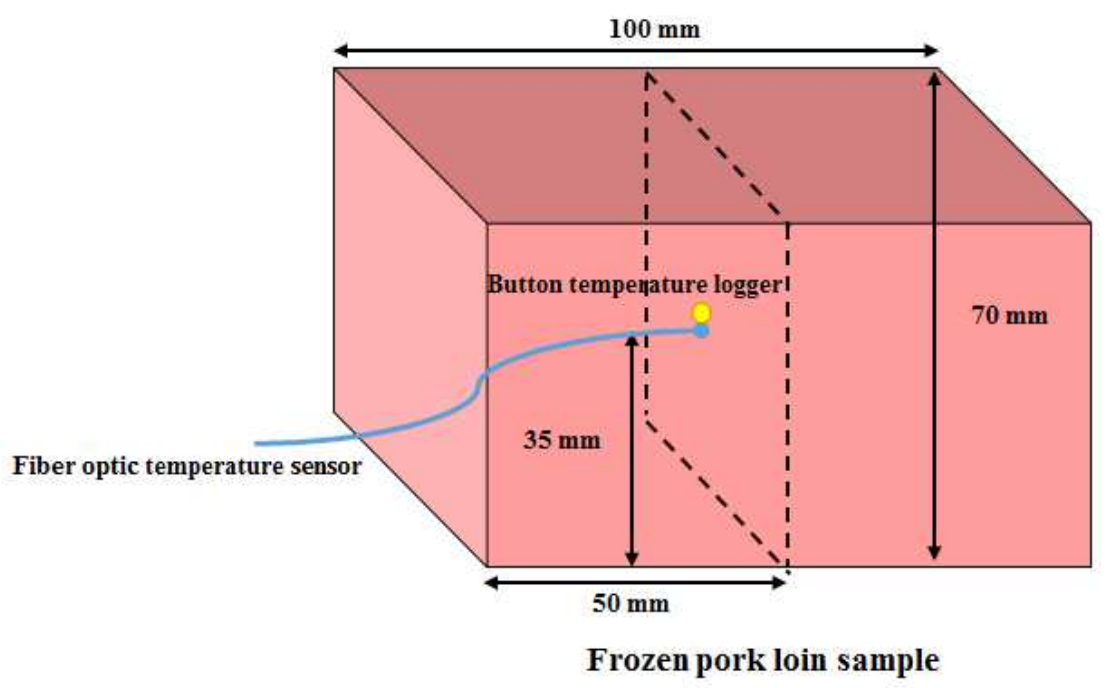

(b)

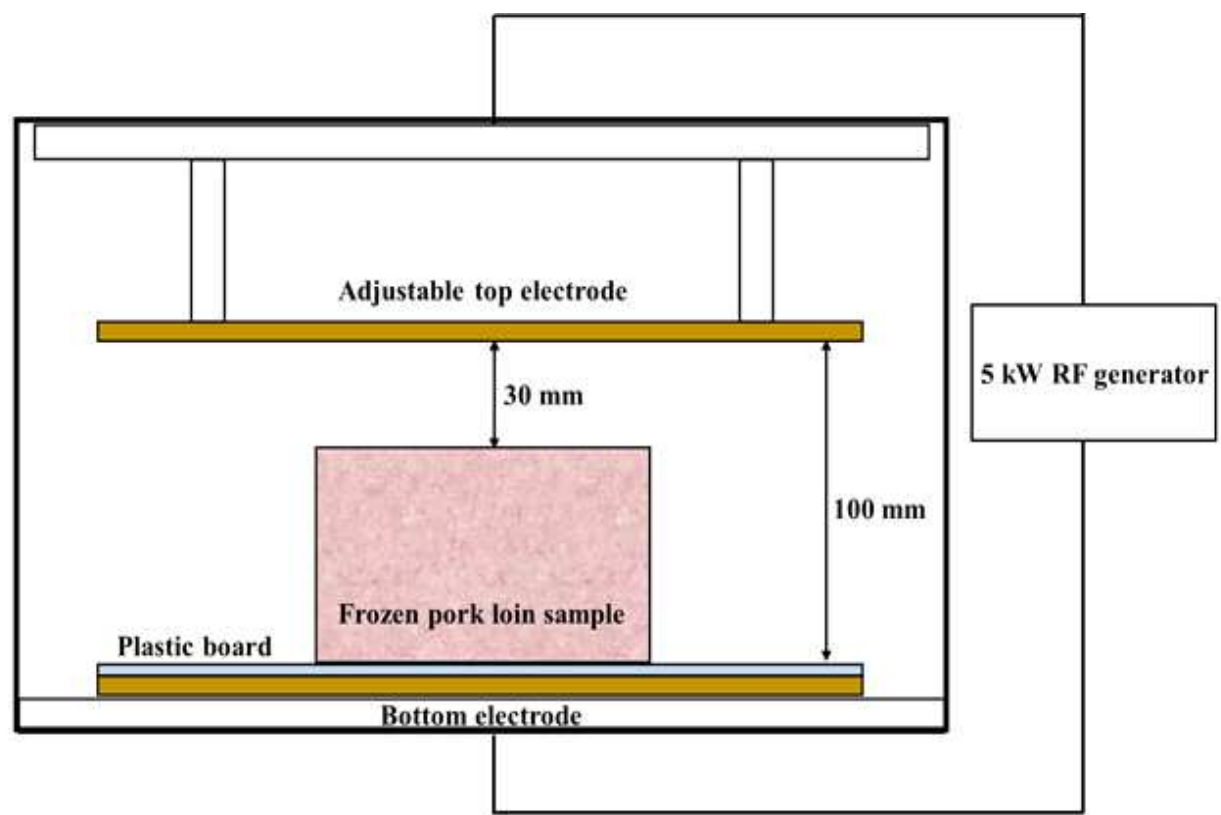

Fig. 1. Schematic representation of the temperature sensor location of the frozen pork loin (a) and thawing at $27.12 \mathrm{MHz}$ radio frequency (b). 
저온 $\left(4^{\circ} \mathrm{C}\right)$ 과 상온 $\left(15^{\circ} \mathrm{C}\right)$ 조건으로 저장하였다. 저장 중 시료 의 이화학적, 미생물학적 및 관능적 품질평가를 실시하였 고 냉동과 해동 처리를 하지 않은 신선 돈육을 대조구로 비교하였다.

\section{저장 중 드립감량과 보수력 측정}

드립감량은 포장 전 시료 무게와 저장 중 포장을 개봉하 여 시료 표면의 수분을 제거한 다음 시료의 무게를 측정하 여 백분율(\%)로 나타내었다. 보수력은 원심분리법을 이용 하여 측정하였다(22). Amicon ultra centrifugal filter(Ultracel$100 \mathrm{~K}$, Merck Millipore Ltd., Cork, Ireland)에 세절된 시료 $3 \mathrm{~g}$ 을 정확히 취한 후 $70^{\circ} \mathrm{C}$ water bath에서 30 분 가열하였다. 실온에서 10 분간 방랭 후 $20^{\circ} \mathrm{C}$ 에서 $2,000 \times g$ 로 10 분간 원심 분리로 분리된 육즙량과 시료의 총 수분량을 측정하여 백분 율 $(\%)$ 로 나타내었다.

\section{저장 중 단백질변패도와 지방산패도 측정}

저장 중 시료의 단백질변패 정도를 나타내는(TVBN) 함 량은 Conway 미량 확산법을 이용하여 측정하였다(23). 세 절된 시료 $10 \mathrm{~g}$ 에 증류수 $90 \mathrm{~mL}$ 를 가하여 균질화한 후 여과지(Whatman No. 1, Fisher Scientific Inc., Fair Lawn, $\mathrm{NJ}, \mathrm{USA}$ )를 이용하여 여과한 여과액을 시험용액으로 하였 다. Conway unit 외실에 시험용액 $1 \mathrm{~mL}$ 와 확산기의 내실에 $0.01 \mathrm{~N} \mathrm{H}_{2} \mathrm{SO}_{4}$ 용액 $1 \mathrm{~mL}$ 를 각각 넣은 후 $37^{\circ} \mathrm{C}$ 에서 120 분 반응시켰다. 반응 후 내실에 Conway reagent $(0.07 \%$ methyl red/0.07\% bromocresol green)를 1-2방울 적하하고 $0.01 \mathrm{~N}$ $\mathrm{NaOH}$ 를 이용해 적정하여 TVBN 함량을 측정하였다. 공시 험은 시료 대신 $20 \% \mathrm{TCA}$ 용액을 사용하였다.

지방산패도를 나타내는 thiobarbituric acid reactive substance(TBARS) 함량은 Nam 등(24)의 방법을 참고하여 측정하였다. 세절된 시료 $5 \mathrm{~g}$ 을 취하여 증류수 $15 \mathrm{~mL}$ 와 함께 균질화 후 여과하였다. 여과된 시료 $1 \mathrm{~mL}$ 에 thiobarbituric acid(TBA)/trichloroacetic $\operatorname{acid}(\mathrm{TCA}) 2 \mathrm{~mL}$ 와 $7.2 \%$ butylated hydroxy toluene(BHT) $50 \mu \mathrm{L}$ 를 첨가한 후 $90^{\circ} \mathrm{C}$ boiling water bath에서 15 분간 가열하였다. $2,000 \times \mathrm{g}$ 에 서 10 분간 원심분리 후 상등액을 취해 UV-visible spectrophotometer(UV-1800, Shimadzu Scientific Instruments Inc., Columbia, MD, USA)를 이용하여 $532 \mathrm{~nm}$ 에서 흡광도 를 측정하였다. TBARS 함량은 시료 $\mathrm{kg}$ 당 malonaldehyde (MDA) $\mathrm{mg}$ 으로 나타내어 표시하였다.

\section{저장 중 색도 측정}

저장 중 돈육 시료 표면의 색도는 색차계(Chroma meter CR-400, Konica Minolta Sensing Inc., Osaka, Japan)를 이용 하여 표준백판 $\left(\mathrm{L}^{*}=98.86, \mathrm{a}^{*}=-0.28, \mathrm{~b}^{*}=4.06\right)$ 으로 보정 후 측 정하였다. Hunter $\mathrm{L}^{*}$ (lightness), $\mathrm{a}^{*}$ (redness)와 $\mathrm{b}^{*}$ (yellowness) 값은 각 시료의 표면을 10 회 이상 반복하여 평균표준편차
로 나타내었다. 색차를 나타내는 $\Delta \mathrm{E}^{*}$ 값은 아래의 수식을 이용하여 측정하였다.

$$
\Delta \mathrm{E}^{*}=\left[\left(\mathrm{L}^{*}-\mathrm{L}_{0}^{*}\right)^{2}+\left(\mathrm{a}^{*}-\mathrm{a}_{0}{ }^{*}\right)^{2}+\left(\mathrm{b}^{*}-\mathrm{b}_{0}\right)^{*}\right]^{1 / 2}
$$

저장 중 미생물 수 측정

저장 중 돈육의 미생물 수 변화를 분석하기 위해 시료 $25 \mathrm{~g}$ 과 $0.1 \%$ 멸균 펩톤수 $225 \mathrm{~mL}$ 를 멸균 필터bag에 넣은 후 stomacher(Bagmixer R400, Interscience Inc., Saint Nom, France)를 이용해 3 분간 균질화 시켰다. $0.1 \%$ 멸균 펩톤수 로 균질화 된 용액을 10 배수 연속 희석한 후 희석액 $1 \mathrm{~mL}$ 를 각각의 배지에 분주하였다. 총 호기성 세균은 $3 \mathrm{M}$ Petrifilm $^{\mathrm{TM}}$ aerobic count plate(Petrifilm AC, 3M Co., St. Paul, MN, USA)를 사용하여 $37^{\circ} \mathrm{C}$ 에서 48 시간 배양 후 붉은 집락수를 계수하였다. 대장균군은 coliform count plate (Petrifilm CC, $3 \mathrm{M} \mathrm{Co}$ )를 사용하여 $37^{\circ} \mathrm{C}$ 에서 24 시간 배양 후 기포가 생성된 붉은 집락수를 계수하였다. 효모 및 곰팡 이는 yeast and mold count plate(Petrifilm YM, 3M Co.)를 사용하여 $25^{\circ} \mathrm{C}$ 에서 72 시간 배양 후 녹푸른색 집락수를 계수 하였다. 검출된 미생물 수는 시료 $\mathrm{g}$ 당 colony forming unit(CFU)로 나타냈고 3회 반복하여 측정하였다.

\section{관능검사}

저장 중 돈육 시료의 관능검사는 사전 교육을 받은 20 명 의 패널로 시료의 신선도, 외관, 조직감, 냄새, 전체적인 품질을 9점 hedonic scale(9-8, 매우 좋음; 7-6, 좋음; 5-4, 보통; 3-2, 나쁨; 1 , 매우 나쁨)을 사용하여 실시하였다.

\section{통계처리}

모든 실험은 3회 반복하여 측정하였으며 실험 결과는 평균값 \pm 표준편차로 나타냈다. 처리평균 간의 유의성 검정 은 SPSS(Statistical Package for the Social Science, Version 19, SPSS Inc., Chicago, IL, USA) program을 이용하여 $\mathrm{p}<0.05$ 수준에서 Duncan's multiple range test 방법으로 다중 비교를 실시하였다.

\section{결과 및 고찰}

\section{냉동 돈육의 급속 해동방법 선정}

냉동 돈육의 해동은 시료의 중심온도가 $0^{\circ} \mathrm{C}$ 에 도달하였 을 때 완료로 하였으며 다양한 해동방법에 따른 냉동 돈육 의 해동완료까지 소요시간은 Fig. 2에 나타냈다. 4 와 $10^{\circ} \mathrm{C}$ 송풍식 해동처리구의 해동시간은 각각 753.5 과 411.5 분, 4 와 $10^{\circ} \mathrm{C}$ 유수식 해동처리구는 각각 417 과 291 분으로 해동 방법과 온도에 따라 유의적인 $(\mathrm{p}<0.05)$ 차이를 보였다. 라디 오파 해동처리구의 해동시간은 20.5 분으로 다른 해동방법 
에 비해 가장 신속히 해동이 완료되는 결과를 보였다. 특히 $4^{\circ} \mathrm{C}$ 송풍식 해동처리구와 비교하여 약 $1 / 37$ 배 수준으로 해 동시간을 단축시킬 수 있었다. 또한 송풍식과 유수식 해동 에 비해 라디오파 해동은 냉동 돈육이 상전이가 개시되는 $-5^{\circ} \mathrm{C}$ 에서 $0^{\circ} \mathrm{C}$ 까지 빠르게 상승시켰다.

일반적으로 냉동 원료육 해동 시 특별한 장비가 필요 없는 송풍식 또는 유수식 방법을 이용한다. 하지만 기존 열전도 방식에 의한 해동은 냉동육의 표면에 녹아 있는 물이 얼음보다 열 흡수가 빠르기 때문에 중심 부위까지 열전달을 막아 해동시간이 길고 드립 유출, 보수력 감소 및 미생물 증식과 같은 품질변화가 발생하는 단점이 있다 (25). $27.12 \mathrm{MHz}$ 라디오파는 $2,450 \mathrm{MHz}$ 마이크로파에 비해 투과 깊이가 깊어 냉동육의 내부 물분자에 마찰열이 균일하 게 발생하여 급속 및 균일 해동이 가능하다(26). 또한 냉동 육의 짧은 해동시간은 시장 수요에 맞춰 해동육을 적절히 공급하여 식육가공품 생산량의 변동에 즉시 대응할 수 있 다. Llave 등 (27)은 $-40^{\circ} \mathrm{C}$ 로 동결한 냉동 참치를 라디오파 해동방법을 이용하여 $-3^{\circ} \mathrm{C}$ 까지 해동 완료한 결과 참치 시료 의 상부, 중부, 하부에서 부분가열 현상 없이 균일한 온도 분포를 나타냈다고 보고하였다. Farag 등(13)은 $4 \mathrm{~kg}$ 냉동 우육 블록이 $0^{\circ} \mathrm{C}$ 까지 도달하는데 강제 송풍식 해동은 3,020 분 소요된 반면 라디오파 해동은 35 분으로 해동시간을 약 85 배 감소하였다고 보고하였다. 따라서 본 연구결과를 토 대로 저장 전 냉동 돈육 시료의 급속 해동방법으로 27.12 $\mathrm{MHz}$ 라디오파 해동을 선정하였다.

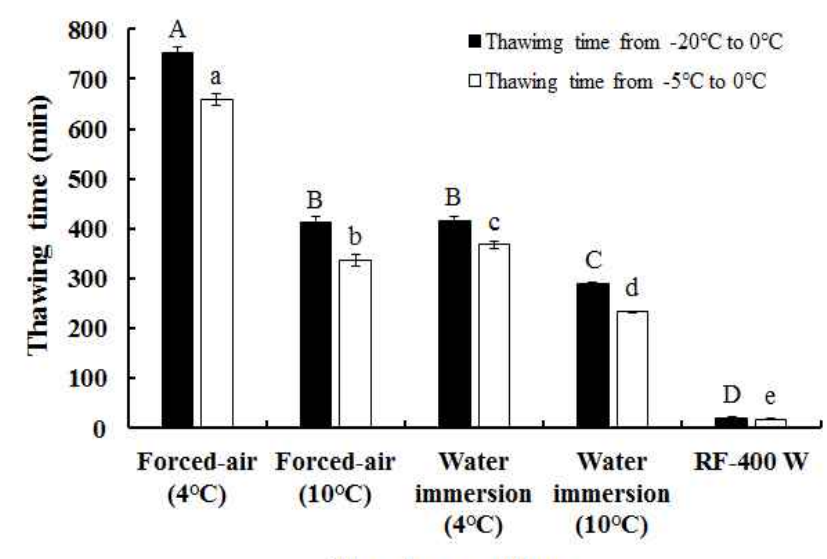

Thawing conditions

Fig. 2. Time required for thawing of frozen pork loins under six different tempering conditions.

Means with different letters differ significantly $(\mathrm{p}<0.05)$ at the same color graph bar.

\section{냉각온도에 따른 돈육의 미세구조 변화}

돈육의 과냉각 저장온도를 선정하기위해 다양한 영하온 도로 냉각 처리했을 때 나타나는 돈육 횡단면의 미세구조 변화를 관찰하였다(Fig. 3). 냉각 전 신선 돈육의 경우 시료 표면과 중심부에 근원섬유 횡단면이 균일하며 얼음결정 형성으로 인해 발생하는 근섬유 내의 공간(intracellular space)이 관찰되지 않았다. $-1.5^{\circ} \mathrm{C}$ 에서 냉각 처리된 시료의 표면과 중심부는 냉각 전과 비교하여 세포 내부에 공간이나 세포 외부에 뚜렷한 근섬유 사이의 공간이 보이지 않았으며 규칙적으로 빼곡한 배열이 관찰되어 동결에 의한 조직 손상 이 발생하지 않았음을 확인하였다. $-2.5^{\circ} \mathrm{C}$ 로 냉각 처리된 돈육 시료의 중심부는 구조적 손상이나 변화 없이 냉각 전 또는 $-1.5^{\circ} \mathrm{C}$ 에서 냉각 처리된 시료와 유사한 것으로 나타 났다. 반면 $-2.5^{\circ} \mathrm{C}$ 로 냉각 처리된 시료 표면의 근섬유 조직에 빈 공간이 관찰되어 이는 $-2.5^{\circ} \mathrm{C}$ 냉각 중 표면 조직에 분포하 고 있는 수분이 동결하여 얼음결정으로 존재하였음을 판단 할 수 있는 증거로 생각된다.

-3.5 와 $-5^{\circ} \mathrm{C}$ 에서 24 시간 냉각 처리된 돈육 시료의 표면과 중심부는 외관적으로 동결상태를 나타냈다. 또한 표면과 중심부의 근섬유 조직이 불균일하게 뭉쳐져 있고 근섬유 사이의 간격이 더 넓어지거나 근섬유의 배열이 흐트러져 규칙성을 무너뜨리는 현상이 관찰되었다. 이러한 결과는 -3.5 와 $-5^{\circ} \mathrm{C}$ 에서 완만 동결 중 세포 내외부에 얼음결정이 크게 성장하여 덩어리상의 형태를 구성하거나 해동 중 조직 내 얼음결정들이 융합되어 큰 결정을 만든 것으로 판단된 다. 본 연구결과는 Jeremiah와 Gibson(28)이 $-1.5^{\circ} \mathrm{C}$ 과냉각 저장 중 우육에 동결이 발생하지 않았다는 보고와 일치하였 다. Fukuma 등(19)은 $-0.8^{\circ} \mathrm{C}$ 저장 1 일 후 도미의 근육 조직에 동결에 의한 손상이 관찰되지 않았고 $-3.8^{\circ} \mathrm{C}$ 저장 $2-8$ 일 동안 근원섬유의 분리는 발생하였지만 얼음결정에 의한 근섬유 손상은 발생하지 않았다고 보고하였다. 따라서 본 연구결과를 통해 돈육의 과냉각 저장을 위한 온도를 $-1.5^{\circ} \mathrm{C}$ 로 선정하였다.

\section{저장 중 드립감량과 보수력 변화}

육류의 드립은 근절 수축과 근육 미세구조의 변화로 근 육 내 수분이 외부로 유출되어 발생한다(22). 특히 냉동-해 동처리로 발생한 드립은 육류에 오염된 미생물 생장과 품질 저하에 원인이 될 수 있다 $(9,10)$. 저장 중 냉동-해동 처리된 돈육의 드립감량 변화는 Fig. 4 와 같다. 저장 2 일 후 -1.5 , 4 와 $15^{\circ} \mathrm{C}$ 에 저장한 대조구의 드립감량은 각각 $1.73,2.06$ 과 $2.81 \%$ 였으며 냉동-해동 처리구의 드립감량은 각각 2.69 , 8.42 와 $10.58 \%$ 로 나타나 저장온도가 높을수록 드립감량은 증가하였다. 또한 대조구인 신선육과 비교하여 냉동-해동 처리된 돈육에서 발생한 드립감량이 저장기간 동안 유의적 으로 $(\mathrm{p}<0.05)$ 높은 경향을 보였다. $4^{\circ} \mathrm{C}$ 저장 10 일 후 냉동-해 동처리구의 드립감량은 $14.72 \%$ 까지 증가한 반면 $-1.5^{\circ} \mathrm{C}$ 저 장한 냉동-해동 처리구는 $9.48 \%$ 로 과냉각 저장온도가 돈육 의 드립발생 억제 효과를 나타냈다. 일반적으로 완만 냉동 에 의해 육류 조직세포가 손상을 많이 받은 경우와 장시간 해동으로 드립감량이 증가하는 것으로 보고(3)되고 있기에 육류의 냉동 및 해동 처리 시 본 연구에서 이용한 초저온 액체 침지식 급속 냉동과 라디오파 급속 해동방법이 바람직 
할 것으로 보인다.

육류의 보수력은 물리적 작용을 받았을 때 수분을 잃지 않고 보유할 수 있는 능력으로 육류의 색, 연도, 다즙성에 영향을 주는 요인이다(29). 저장 초기 대조구와 냉동-해동 처리구의 보수력은 각각 62.44 와 $61.44 \%$ 로 유의적인 $(\mathrm{p}<0.05)$ 차이는 보이지 않았다(Table 1). 냉동육은 근원섬 유 내에 얼음결정이 형성됨에 따라 미오신 구조가 손상되고
단백질 변성에 의해 보수력이 감소하는 것으로 보고된 바 있다(30). 그러나 본 연구에서는 침지식 급속 냉동 및 라디 오파 급속 해동처리 직후 돈육의 보수력 변화에 큰 영향을 주지 않은 것으로 관찰되었다. 저장 10 일 후 $4^{\circ} \mathrm{C}$ 에 저장한 대조구와 냉동-해동 처리구의 보수력은 각각 70.22 와 $71.44 \%$ 로 저장기간이 경과함에 따라 증가하는 경향을 보였 다. 저장 중 돈육의 보수력 변화는 단백질 분해와 $\mathrm{pH}$ 변화에

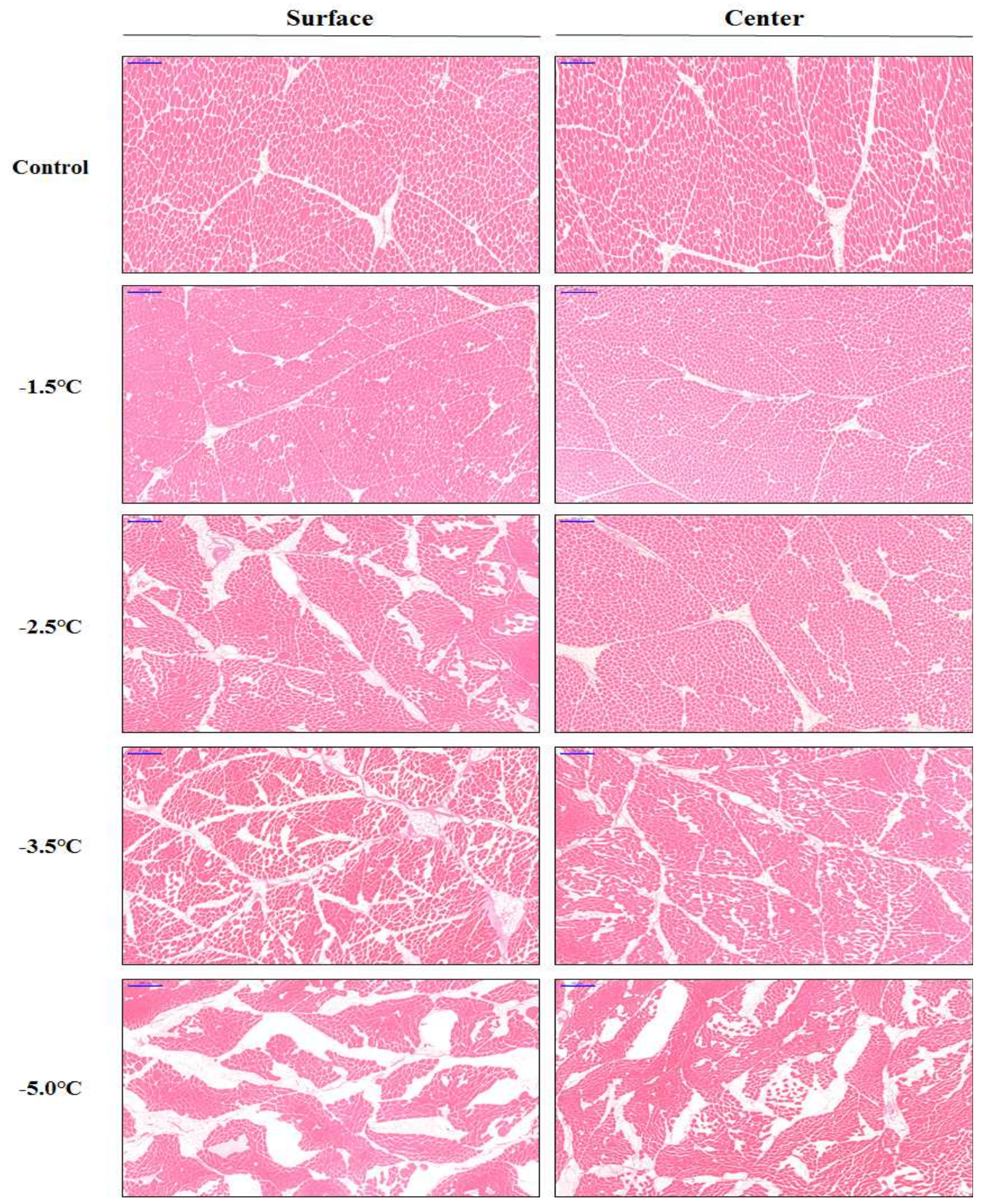

Fig. 3. Light microscope images of transverse sections of pork loin samples treated with different cooling conditions. Magnification was $\times 3$ and the scale bar indicates $500 \mu \mathrm{m}$. 
기인한다(31). Ko 등(32)은 저장 초기 돈육의 보수력은 $75 \%$ 로 $4^{\circ} \mathrm{C}$ 저장 15 일 후 $87.50 \%$ 까지 증가했다고 보고하였으며 Moon 등(2)은 냉동-해동 처리된 돈육의 보수력이 $43.18 \%$ 였 으나 저온 저장 4 일 후 $52.78 \%$ 로 증가하는 것으로 보고하여 본 연구와 유사한 결과를 나타냈다. 한편 4 또는 $15^{\circ} \mathrm{C}$ 저장 과 비교하여 $-1.5^{\circ} \mathrm{C}$ 저장된 대조구와 냉동-해동 처리구의 보수력 변화 폭이 작게 나타났다.

\section{저장 중 단백질변패도와 지방산패도 변화}

$-1.5,4$ 와 $15^{\circ} \mathrm{C}$ 저장 중 돈육의 TVBN과 TBARS 함량 변화는 Table 2 에 나타내었다. 저장 초기의 대조구와 냉동해동 처리구의 TVBN 함량은 각각 7.84 와 $7.44 \mathrm{mg} \mathrm{N} / 100$ $\mathrm{g}$ 으로 신선 돈육의 TVBN 함량이 약 $8 \mathrm{mg} \mathrm{N} / 100 \mathrm{~g}$ 이었다는 Tak 등(4)의 연구결과와 유사한 수준으로 나타났다. 저장 4 일 후, $15^{\circ} \mathrm{C}$ 저장한 대조구와 냉동-해동 처리구의 TVBN 함량은 각각 15.70 과 $12.29 \mathrm{mg} \mathrm{N} / 100 \mathrm{~g}$ 으로 높은 저장 온도
가 돈육의 TVBN 함량 증가에 영향을 주는 것으로 나타났 다. 또한 $4^{\circ} \mathrm{C}$ 저장 10 일 후, 대조구와 냉동-해동 처리구의 TVBN 함량은 13.78 과 $12.14 \mathrm{mg} \mathrm{N} / 100 \mathrm{~g}$ 까지 증가하였다. 시료간 저장온도 비교에서 $-1.5^{\circ} \mathrm{C}$ 저장한 대조구와 냉동-해 동처리구가 4 와 $15^{\circ} \mathrm{C}$ 저장에 비해 유의적으로 $(\mathrm{p}<0.05)$ 낮은 TVBN 함량 증가를 보였다.

육류의 저장 중 미생물 분비 효소들에 의해 근육 단백질 이 아미노산과 여러 무기태 질소로 분해되어 TVBN 휘발성 염기질소 함량은 증가한다(25). 또한 육류에 미생물 오염도 가 높을수록 휘발성 염기질소의 함량이 증가하기 때문에 휘발성 염기질소 함량은 육류의 신선도를 평가하는데 중요 한 지표이다(4). 식품공전에서 원료육과 포장육의 휘발성 염기질소 함량은 $20 \mathrm{mg} \mathrm{N} / 100 \mathrm{~g}$ 이하로 규정하고 있다. 본 연구결과 $-1.5^{\circ} \mathrm{C}$ 과냉각 온도에서 저장은 돈육의 단백질 변패 억제 효과를 나타낸 것으로 확인하였다.

Table 1 . Changes in the water holding capacity of fresh and frozen-thawed pork loins during storage at $-1.5,4$, and $15^{\circ} \mathrm{C}$

\begin{tabular}{|c|c|c|c|c|c|c|c|c|}
\hline \multirow{2}{*}{ Parameter } & \multirow{2}{*}{ Treatment } & \multirow{2}{*}{$\begin{array}{c}\text { Storage } \\
\text { temperature }\left({ }^{\circ} \mathrm{C}\right)\end{array}$} & \multicolumn{6}{|c|}{ Storage period (day) } \\
\hline & & & 0 & 2 & 4 & 6 & 8 & 10 \\
\hline \multirow{6}{*}{$\begin{array}{c}\text { Water holding } \\
\text { capacity } \\
(\%)\end{array}$} & \multirow{3}{*}{$\begin{array}{l}\text { Control } \\
\text { (fresh) }\end{array}$} & 15 & $62.44 \pm 1.68^{1) \mathrm{Ab2} 2}$ & $62.11 \pm 1.90^{\mathrm{ABb}}$ & $65.56 \pm 0.69^{\mathrm{Aa}}$ & - & - & - \\
\hline & & 4 & $62.44 \pm 1.68^{\mathrm{Aa}}$ & $60.44 \pm 0.84^{\mathrm{ABa}}$ & $66.00 \pm 0.58^{\mathrm{Ab}}$ & $68.64 \pm 0.67^{\mathrm{Aa}}$ & $70.11 \pm 0.84^{\mathrm{Aa}}$ & $70.22 \pm 1.35^{\mathrm{Aa}}$ \\
\hline & & -1.5 & $62.44 \pm 1.68^{\mathrm{Aab}}$ & $60.67 \pm 1.65^{\mathrm{Bb}}$ & $62.44 \pm 1.54^{\mathrm{Bab}}$ & $64.11 \pm 1.84^{\mathrm{Ba}}$ & $65.00 \pm 1.53^{\mathrm{Ba}}$ & $65.56 \pm 1.50^{\mathrm{Ba}}$ \\
\hline & \multirow{3}{*}{$\begin{array}{l}\text { Frozen- } \\
\text { thawed }\end{array}$} & 15 & $61.44 \pm 1.67^{\mathrm{Ab}}$ & $62.44 \pm 1.35^{\mathrm{ABb}}$ & $66.67 \pm 1.00^{\mathrm{Aa}}$ & - & - & - \\
\hline & & 4 & $61.44 \pm 1.67^{\mathrm{Ac}}$ & $63.56 \pm 1.17^{\mathrm{Ac}}$ & $67.11 \pm 1.17^{\mathrm{Ab}}$ & $68.56 \pm 2.01^{\mathrm{Ab}}$ & $69.44 \pm 1.34^{\mathrm{Aab}}$ & $71.44 \pm 1.22^{\mathrm{Aa}}$ \\
\hline & & -1.5 & $61.44 \pm 1.67^{\mathrm{Abc}}$ & $60.89 \pm 1.26^{\mathrm{ABbc}}$ & $60.22 \pm 1.41^{\mathrm{Cc}}$ & $61.00 \pm 1.73^{\mathrm{Cbc}}$ & $63.44 \pm 0.84^{\mathrm{Bab}}$ & $64.22 \pm 1.55^{\mathrm{Ba}}$ \\
\hline
\end{tabular}

${ }^{1)}$ Each value is mean $\pm \mathrm{SD}$.

${ }^{2)}$ Mean values in the same column (A-C) or row (a-c) followed by different letters are significantly different according to Duncan's multiple range test ( $<<0.05$ ).

Table 2. Changes in TVBN and TBARS of fresh and frozen-thawed pork loins during storage at $-1.5,4$, and $15^{\circ} \mathrm{C}$

\begin{tabular}{|c|c|c|c|c|c|c|c|c|}
\hline \multirow{2}{*}{ Parameter } & \multirow{2}{*}{ Treatment } & \multirow{2}{*}{$\begin{array}{c}\text { Storage } \\
\text { temperature }\left({ }^{\circ} \mathrm{C}\right)\end{array}$} & \multicolumn{6}{|c|}{ Storage period (day) } \\
\hline & & & 0 & 2 & 4 & 6 & 8 & 10 \\
\hline \multirow{6}{*}{$\begin{array}{c}\text { TVBN } \\
(\mathrm{mg} \mathrm{N} / 100 \mathrm{~g})\end{array}$} & \multirow{3}{*}{$\begin{array}{l}\text { Control } \\
\text { (fresh) }\end{array}$} & 15 & $7.84 \pm 0.99^{1 \mathrm{~A} A(2)}$ & $9.95 \pm 0.89^{\mathrm{Ab}}$ & $15.70 \pm 0.80^{\mathrm{Aa}}$ & - & - & - \\
\hline & & 4 & $7.84 \pm 0.99^{\mathrm{Ad}}$ & $9.67 \pm 0.92^{\mathrm{Ac}}$ & $10.74 \pm 0.93^{\mathrm{Cbc}}$ & $11.50 \pm 0.53^{\mathrm{Ab}}$ & $13.18 \pm 0.55^{\mathrm{Aa}}$ & $13.78 \pm 0.53^{\mathrm{Az}}$ \\
\hline & & -1.5 & $7.84 \pm 0.99^{\mathrm{Ad}}$ & $9.41 \pm 0.48^{\mathrm{Ac}}$ & $9.54 \pm 0.71^{\mathrm{Dc}}$ & $9.62 \pm 0.48^{\mathrm{Bbc}}$ & $10.81 \pm 0.63^{\mathrm{Bab}}$ & $10.88 \pm 0.61^{\mathrm{Ca}}$ \\
\hline & \multirow{3}{*}{$\begin{array}{l}\text { Frozen- } \\
\text { thawed }\end{array}$} & 15 & $7.44 \pm 0.61^{\mathrm{Ab}}$ & $8.00 \pm 0.96^{\mathrm{Bb}}$ & $12.29 \pm 0.43^{\mathrm{Ba}}$ & - & - & - \\
\hline & & 4 & $7.44 \pm 0.61^{\mathrm{Ad}}$ & $7.72 \pm 0.49^{\mathrm{Bdd}}$ & $8.76 \pm 0.28^{\mathrm{DEc}}$ & $10.34 \pm 0.49^{\mathrm{Bb}}$ & $11.19 \pm 1.28^{\mathrm{Bab}}$ & $12.14 \pm 0.25^{\mathrm{Ba}}$ \\
\hline & & -1.5 & $7.44 \pm 0.61^{\mathrm{Ab}}$ & $7.54 \pm 0.42^{\mathrm{Bb}}$ & $7.68 \pm 0.35^{\mathrm{Eb}}$ & $8.31 \pm 0.48^{\mathrm{Cb}}$ & $10.25 \pm 0.29^{\mathrm{Ba}}$ & $10.27 \pm 0.58^{\mathrm{Ca}}$ \\
\hline \multirow{6}{*}{$\begin{array}{c}\text { TBARS } \\
(\mathrm{mg} \mathrm{MDA} / \mathrm{kg})\end{array}$} & \multirow{3}{*}{$\begin{array}{l}\text { Control } \\
\text { (fresh) }\end{array}$} & 15 & $0.18 \pm 0.03^{\mathrm{Aa}}$ & $0.19 \pm 0.01^{\mathrm{ABa}}$ & $0.20 \pm 0.01^{\mathrm{Aa}}$ & - & - & - \\
\hline & & 4 & $0.18 \pm 0.03^{\mathrm{Ac}}$ & $0.18 \pm 0.02^{\mathrm{BC}}$ & $0.19 \pm 0.02^{\mathrm{Abc}}$ & $0.20 \pm 0.01^{\mathrm{Abc}}$ & $0.22 \pm 0.01^{\mathrm{Aab}}$ & $0.24 \pm 0.02^{\mathrm{Aa}}$ \\
\hline & & -1.5 & $0.18 \pm 0.03^{\mathrm{Aa}}$ & $0.18 \pm 0.01^{\mathrm{Ba}}$ & $0.18 \pm 0.01^{\mathrm{Aa}}$ & $0.18 \pm 0.02^{\mathrm{Aa}}$ & $0.18 \pm 0.01^{\mathrm{Ba}}$ & $0.18 \pm 0.02^{\mathrm{Ba}}$ \\
\hline & \multirow{3}{*}{$\begin{array}{l}\text { Frozen- } \\
\text { thawed }\end{array}$} & 15 & $0.18 \pm 0.01^{\mathrm{Aa}}$ & $0.22 \pm 0.03^{\mathrm{Aa}}$ & $0.21 \pm 0.02^{\mathrm{Aa}}$ & - & - & - \\
\hline & & 4 & $0.18 \pm 0.01^{\mathrm{Ab}}$ & $0.18 \pm 0.02^{\mathrm{Bb}}$ & $0.18 \pm 0.01^{\mathrm{Ab}}$ & $0.20 \pm 0.02^{\mathrm{Ab}}$ & $0.23 \pm 0.01^{\mathrm{Aa}}$ & $0.25 \pm 0.01^{\mathrm{Aa}}$ \\
\hline & & -1.5 & $0.18 \pm 0.01^{\mathrm{Aa}}$ & $0.17 \pm 0.02^{\mathrm{Ba}}$ & $0.18 \pm 0.02^{\mathrm{Aa}}$ & $0.18 \pm 0.02^{\mathrm{Aa}}$ & $0.18 \pm 0.01^{\mathrm{Ba}}$ & $0.17 \pm 0.02^{\mathrm{Ba}}$ \\
\hline
\end{tabular}

\footnotetext{
${ }^{1)}$ Each value is mean \pm SD.

${ }^{2)}$ Mean values in the same column (A-E) or row (a-d) followed by different letters are significantly different according to Duncan's multiple range test ( $<<0.05$ )
} 
저장 초기 대조구와 냉동-해동 처리구의 TBARS 함량은 $0.18 \mathrm{mg} \mathrm{MDA} / \mathrm{kg}$ 으로 뚜렷한 차이를 보이지 않아 액체 침 지식 냉동과 라디오파 해동처리가 돈육의 지방산패에 영향 을 주지 않은 것으로 나타났다(Table 2). 저장 10 일 후, $4^{\circ} \mathrm{C}$ 저장한 대조구와 냉동-해동 처리구의 TBARS 함량은 각각 0.24 와 $0.25 \mathrm{mg} \mathrm{MDA} / \mathrm{kg}$ 로 저장초기에 비해 증가하였다. 이는 저장 중 육류의 지방질 산화 및 지방분해효소에 의해 하이드로과산물이 생성되고 미생물에 의한 산화가 이루어 져 알데하이드, 케톤 등 카보닐 화합물의 증가에 의한 것으 로 생각된다. 반면 $-1.5^{\circ} \mathrm{C}$ 저장한 대조구와 냉동-해동 처리 구는 각각 0.18 와 $0.17 \mathrm{mg} \mathrm{MDA} / \mathrm{kg}$ 으로 저장 초기와 유사한 수준을 유지하여 저장기간에 따른 유의적인 $(\mathrm{p}<0.05)$ 차이 가 인정되지 않았다. 따라서 본 연구결과 $-1.5^{\circ} \mathrm{C}$ 과냉각 저장 은 돈육의 단백질 변패와 지방산패 억제 효과를 나타낸 것으로 확인하였다.

\section{저장 중 색도 변화}

육류의 색은 소비자가 식육을 구입하는데 중요하게 고려 하는 요인 중 하나로 저장 중 육색의 변화는 $\mathrm{pH}$, 지질 산화, 미생물 증식 등 많은 요인이 작용한다(33). 저장 초기, 냉동해동 처리구의 $\mathrm{L}^{*}, \mathrm{a}^{*}$ 과 $\mathrm{b}^{*}$ 값은 각각 $47.30,8.32$ 과 2.91 으로 대조구와 유의적인(p<0.05) 차이를 보이지 않았다(Table 3). 저장기간이 경과함에 따라 $\mathrm{L}^{*}$ 값은 유의적으로 $(\mathrm{p}<0.05)$ 증 가하여 $4^{\circ} \mathrm{C}$ 저장 10 일 후 대조구와 냉동-해동 처리구는 각각 54.14 와 53.62로 나타났다. Lee 등(34)은 돈육 등심의 $\mathrm{L}^{*}$ 값은 저장 초기에 51.66 이였지만 $4^{\circ} \mathrm{C}$ 저장 12 일 후 55.84 로 증가하였다고 보고하였는데 본 연구 결과와 유사하였다.

한편 대조구와 냉동-해동 처리구의 $\mathrm{a}^{*}$ 값은 저장 기간에 따라 감소하는 경향을 보였지만 $4^{\circ} \mathrm{C}$ 저온 저장과 비교하여 $-1.5^{\circ} \mathrm{C}$ 과냉각 저장에서 $\mathrm{a}^{*}$ 값의 감소는 지연되는 것으로 나타났다. $\mathrm{a}^{*}$ 값과 반대로 돈육 시료의 $\mathrm{b}^{*}$ 값은 저장기간

Table 3. Changes in the color of fresh and frozen-thawed pork loins during storage at $-1.5,4$, and $15^{\circ} \mathrm{C}$

\begin{tabular}{|c|c|c|c|c|c|c|c|c|}
\hline \multirow{2}{*}{$\begin{array}{l}\text { Colour } \\
\text { parameter }\end{array}$} & \multirow{2}{*}{ Treatment } & \multirow{2}{*}{$\begin{array}{c}\text { Storage } \\
\text { temperature }\left({ }^{\circ} \mathrm{C}\right)\end{array}$} & \multicolumn{6}{|c|}{ Storage period (day) } \\
\hline & & & 0 & 2 & 4 & 6 & 8 & 10 \\
\hline \multirow{6}{*}{$\mathrm{L}^{*}$} & \multirow{3}{*}{$\begin{array}{l}\text { Control } \\
\text { (fresh) }\end{array}$} & 15 & $47.36 \pm 1.20^{1) A b 2)}$ & $52.08 \pm 1.08^{\mathrm{ABa}}$ & $52.09 \pm 1.37^{\mathrm{ABCa}}$ & - & - & - \\
\hline & & 4 & $47.36 \pm 1.20^{\mathrm{Ac}}$ & $51.75 \pm 1.06^{\mathrm{ABb}}$ & $54.00 \pm 1.17^{\mathrm{Aa}}$ & $54.75 \pm 1.20^{\mathrm{Aa}}$ & $55.45 \pm 1.52^{\mathrm{Aa}}$ & $54.14 \pm 1.12^{\mathrm{Aa}}$ \\
\hline & & -1.5 & $47.36 \pm 1.20^{\mathrm{Ab}}$ & $50.30 \pm 2.37^{\text {BCab }}$ & $49.27 \pm 2.13^{\mathrm{Cab}}$ & $47.84 \pm 1.87^{\mathrm{Bb}}$ & $49.05 \pm 2.06^{\mathrm{Bab}}$ & $52.56 \pm 1.82^{\mathrm{Aa}}$ \\
\hline & \multirow{3}{*}{$\begin{array}{l}\text { Frozen- } \\
\text { thawed }\end{array}$} & 15 & $47.30 \pm 1.72^{\mathrm{Ab}}$ & $54.38 \pm 1.48^{\mathrm{Aa}}$ & $52.93 \pm 2.75^{\mathrm{ABa}}$ & - & - & - \\
\hline & & 4 & $47.30 \pm 1.72^{\mathrm{Ab}}$ & $50.92 \pm 1.56^{\mathrm{Ba}}$ & $51.14 \pm 1.27^{\mathrm{ABCa}}$ & $52.78 \pm 1.67^{\mathrm{Aa}}$ & $52.17 \pm 1.90^{\mathrm{ABa}}$ & $53.62 \pm 1.64^{\mathrm{Aa}}$ \\
\hline & & -1.5 & $47.30 \pm 1.72^{\mathrm{Ab}}$ & $47.94 \pm 1.12^{\mathrm{Cb}}$ & $49.61 \pm 1.57^{\mathrm{BCab}}$ & $48.23 \pm 1.86^{\mathrm{Bb}}$ & $49.22 \pm 1.90^{\mathrm{Bab}}$ & $51.88 \pm 1.18^{\mathrm{Aa}}$ \\
\hline \multirow{6}{*}{$a^{*}$} & \multirow{3}{*}{$\begin{array}{l}\text { Control } \\
\text { (fresh) }\end{array}$} & 15 & $7.76 \pm 1.26^{\mathrm{Aa}}$ & $6.37 \pm 0.58^{\mathrm{Cab}}$ & $5.82 \pm 1.01^{\mathrm{Bb}}$ & - & - & - \\
\hline & & 4 & $7.76 \pm 1.26^{\mathrm{Aa}}$ & $6.12 \pm 0.71^{\mathrm{Cab}}$ & $6.75 \pm 0.59^{\mathrm{Ba}}$ & $6.26 \pm 1.66^{\mathrm{Aab}}$ & $4.33 \pm 1.16^{\mathrm{Bb}}$ & $4.31 \pm 1.25^{\mathrm{Cb}}$ \\
\hline & & -1.5 & $7.76 \pm 1.26^{\mathrm{Aab}}$ & $8.20 \pm 1.10^{\mathrm{ABa}}$ & $6.32 \pm 0.76^{\mathrm{Bb}}$ & $6.95 \pm 0.72^{\mathrm{Aab}}$ & $7.13 \pm 0.93^{\mathrm{Aab}}$ & $7.50 \pm 0.83^{\mathrm{Aab}}$ \\
\hline & \multirow{3}{*}{$\begin{array}{l}\text { Frozen- } \\
\text { thawed }\end{array}$} & 15 & $8.32 \pm 1.48^{\mathrm{Aa}}$ & $6.79 \pm 0.79^{\mathrm{BCa}}$ & $6.57 \pm 0.92^{\mathrm{Ba}}$ & - & - & - \\
\hline & & 4 & $8.32 \pm 1.48^{\mathrm{Aa}}$ & $7.50 \pm 0.80^{\mathrm{ABCab}}$ & $6.92 \pm 0.66^{\mathrm{Babc}}$ & $6.49 \pm 0.73^{\mathrm{Abcd}}$ & $5.43 \pm 0.75^{\mathrm{ABcd}}$ & $4.83 \pm 0.81^{\mathrm{BCd}}$ \\
\hline & & -1.5 & $8.32 \pm 1.48^{\mathrm{Aab}}$ & $8.81 \pm 0.69^{\mathrm{Aa}}$ & $8.74 \pm 1.93^{\mathrm{Aa}}$ & $7.06 \pm 1.02^{\mathrm{Aab}}$ & $6.36 \pm 0.86^{\mathrm{Ab}}$ & $6.28 \pm 0.25^{\mathrm{ABb}}$ \\
\hline \multirow{6}{*}{$b^{*}$} & \multirow{3}{*}{$\begin{array}{l}\text { Control } \\
\text { (fresh) }\end{array}$} & 15 & $1.85 \pm 0.83^{\mathrm{Ab}}$ & $1.29 \pm 0.74^{\mathrm{Cb}}$ & $3.56 \pm 0.59^{\mathrm{Ba}}$ & - & - & - \\
\hline & & 4 & $1.85 \pm 0.83^{\mathrm{Ac}}$ & $2.80 \pm 0.84^{\mathrm{BCbc}}$ & $4.48 \pm 0.92^{\mathrm{ABab}}$ & $4.37 \pm 1.12^{\mathrm{Bab}}$ & $5.63 \pm 1.26^{\mathrm{ABa}}$ & $6.09 \pm 0.43^{\mathrm{ABa}}$ \\
\hline & & -1.5 & $1.85 \pm 0.83^{\mathrm{Aa}}$ & $2.38 \pm 1.43^{\mathrm{BCa}}$ & $2.88 \pm 1.16^{\mathrm{Ba}}$ & $2.71 \pm 0.79^{\mathrm{Ba}}$ & $2.45 \pm 1.53^{\mathrm{Ca}}$ & $4.10 \pm 0.95^{\mathrm{Ca}}$ \\
\hline & \multirow{3}{*}{$\begin{array}{l}\text { Frozen- } \\
\text { thawed }\end{array}$} & 15 & $2.91 \pm 1.28^{\mathrm{Ab}}$ & $5.69 \pm 1.68^{\mathrm{Aab}}$ & $6.37 \pm 1.19^{\mathrm{Aa}}$ & - & - & - \\
\hline & & 4 & $2.91 \pm 1.28^{\mathrm{Ab}}$ & $4.24 \pm 1.14^{\mathrm{ABb}}$ & $4.00 \pm 1.41^{\mathrm{Bb}}$ & $6.49 \pm 1.28^{\mathrm{Aa}}$ & $7.06 \pm 1.37^{\mathrm{Aa}}$ & $7.15 \pm 0.68^{\mathrm{Aa}}$ \\
\hline & & -1.5 & $2.91 \pm 1.28^{\mathrm{Ab}}$ & $2.77 \pm 1.24^{\mathrm{BCb}}$ & $3.58 \pm 1.10^{\mathrm{Bab}}$ & $4.76 \pm 0.95^{\mathrm{ABab}}$ & $3.54 \pm 1.19^{\text {BCab }}$ & $5.24 \pm 0.89^{\mathrm{BCa}}$ \\
\hline \multirow{6}{*}{$\Delta \mathrm{E}^{*}$} & \multirow{3}{*}{$\begin{array}{l}\text { Control } \\
\text { (fresh) }\end{array}$} & 15 & - & $5.05 \pm 0.77^{\mathrm{B}}$ & $5.45 \pm 1.22^{\mathrm{AB}}$ & - & - & - \\
\hline & & 4 & - & $4.89 \pm 0.87^{\mathrm{BCc}}$ & $7.25 \pm 1.32^{\mathrm{Ab}}$ & $8.12 \pm 1.13^{\mathrm{Aab}}$ & $9.68 \pm 1.35^{\mathrm{Aa}}$ & $8.85 \pm 0.58^{\mathrm{Aab}}$ \\
\hline & & -1.5 & - & $3.38 \pm 2.33^{\text {BCab }}$ & $3.15 \pm 1.31^{\mathrm{Bab}}$ & $2.07 \pm 0.80^{\mathrm{Bb}}$ & $2.69 \pm 1.41^{\mathrm{Bab}}$ & $5.73 \pm 1.98^{\mathrm{Ba}}$ \\
\hline & \multirow{3}{*}{$\begin{array}{l}\text { Frozen- } \\
\text { thawed }\end{array}$} & 15 & $2.25 \pm 1.18^{\mathrm{Ab}}$ & $8.13 \pm 1.97^{\mathrm{Aa}}$ & $7.40 \pm 2.63^{\mathrm{Aa}}$ & - & - & - \\
\hline & & 4 & $2.25 \pm 1.18^{\mathrm{Ad}}$ & $4.37 \pm 1.83^{\mathrm{BCd}}$ & $4.54 \pm 1.59^{\mathrm{ABbcd}}$ & $7.31 \pm 1.92^{\mathrm{Aabc}}$ & $7.57 \pm 1.91^{\mathrm{Aab}}$ & $8.97 \pm 1.30^{\mathrm{Aa}}$ \\
\hline & & -1.5 & $2.25 \pm 1.18^{\mathrm{Ab}}$ & $1.83 \pm 1.29^{\mathrm{Cb}}$ & $3.30 \pm 2.14^{\mathrm{Bab}}$ & $3.55 \pm 1.04^{\mathrm{Bab}}$ & $3.32 \pm 1.28^{\mathrm{Bab}}$ & $5.86 \pm 1.36^{\mathrm{Ba}}$ \\
\hline
\end{tabular}

\footnotetext{
${ }^{1)}$ Each value is mean $\pm \mathrm{SD}$.

${ }^{2)}$ Mean values in the same column (A-C) or row (a-d) followed by different letters are significantly different according to Duncan's multiple range test $(\mathrm{p}<0.05)$.
} 
중 증가하였으며 특히 $4^{\circ} \mathrm{C}$ 저장 10 일 후 냉동-해동 처리구 의 $\mathrm{b}^{*}$ 값은 7.15 로 가장 높은 값을 보였다. 반면 4 와 $15^{\circ} \mathrm{C}$ 저장과 비교하여 $-1.5^{\circ} \mathrm{C}$ 과냉각 저장은 대조구와 냉동-해동 처리구의 $b^{*}$ 값 증가를 억제하는 효과를 보였다. Jeong 등(5) 은 냉장 저장 동안 신선 돈육에 비해 해동 돈육에서 metmyoglobin의 형성이 촉진되어 육색의 갈색화가 빠르게 진행되었다고 보고하였다. 저장초기 냉동-해동 처리구의 $\Delta \mathrm{E}^{*}$ 값은 1.94 이었으며 $4^{\circ} \mathrm{C}$ 저장 10 일 후 8.97 까지 증가하였 다. 한편 $-1.5^{\circ} \mathrm{C}$ 에 저장한 대조구와 냉동-해동 처리구의 $\Delta \mathrm{E}^{*}$ 값은 각각 5.73 과 5.86 으로 과냉각 저장이 육색 변화를 억제 하는 효과를 확인하였다.

\section{저장 중 미생물 수 변화}

식육의 저장 및 유통 중 위생 상태와 품질에 가장 큰 영향을 미치는 인자는 식육에 생육하는 미생물 수이다(45). 신선 돈육과 냉동 및 해동 처리된 돈육을 $-1.5,4$ 와 $15^{\circ} \mathrm{C}$ 에서 10 일 동안 각각 저장하면서 총 호기성 세균, 대장균군과 효모 및 곰팡이 수를 측정한 결과는 Table 4 와 같다. 저장 초기 신선 돈육인 대조구의 총 호기성 세균 수는 $4.56 \log$ $\mathrm{CFU} / \mathrm{g}$ 인 반면 냉동-해동 처리구는 $4.02 \log \mathrm{CFU} / \mathrm{g}$ 으로 급 속 냉동 및 해동처리로 $0.54 \log \mathrm{CFU} / \mathrm{g}$ 감소를 보였다. 또한 $4{ }^{\circ} \mathrm{C}$ 저장 4 일 후, 냉동-해동 처리구의 총 호기성 세균 수
$4.69 \log \mathrm{CFU} / \mathrm{g}$ 으로 대조구의 $5.50 \log \mathrm{CFU} / \mathrm{g}$ 과 $0.81 \log$ $\mathrm{CFU} / \mathrm{g}$ 차이를 나타냈다. 냉동 및 해동 시 육류에 존재하는 미생물은 농축된 세포 외액에 노출되거나 삼투압 차에 의해 탈수되어 세포 손상을 받거나 사멸한다. Guo 등(35)은 -7 $5^{\circ} \mathrm{C}$ 급속 냉동 처리로 새우의 총 호기성 세균 수를 약 0.5 $\log \mathrm{CFU} / \mathrm{g}$ 감소시킨 결과를 보고하였다. 또한 Haughton 등(37)은 $-30^{\circ} \mathrm{C}$ air blast freezer를 이용한 crust freezing 처리 로 계육에 오염된 Campylobacter jejuni 수를 약 $0.7 \mathrm{log}$ $\mathrm{CFU} / \mathrm{g}$ 감소시켰다고 보고하였다. 육류에 존재하는 미생물 은 도살처리 과정 중 외부환경, 내장, 혈액, 가죽 등에 의하 여 오염되며 저장과 유통 중 교차오염 및 증식의 기회를 갖기 때문에 초기 미생물 오염도를 감소시키기 위한 노력이 필요하다(37). 노르웨이와 아이슬란드 등 유럽에서는 식육 에 오염된 미생물 수준을 감소시키는 방법으로 냉동처리를 활용한다(38).

$15^{\circ} \mathrm{C}$ 저장 4 일 후 대조구와 냉동-해동 처리구의 총 호기 성 세균 수는 각각 9.10 과 $9.30 \log \mathrm{CFU} / \mathrm{g}$ 까지 급격히 증가 하였다. 이때 돈육 시료가 사실상 부패 단계임을 확인하여 $15^{\circ} \mathrm{C}$ 저장한 시료의 실험은 저장 4 일차에 종료하였다. 냉장 저장실의 온도가 $10^{\circ} \mathrm{C}$ 이상이면 식육 표면에 오염된 Pseudomonas 등 호기성 미생물 수가 급격히 증가하고 이는 휘발성 염기질소 증가와 밀접한 관계가 있으며 부패취를

Table 4. Microbial counts (log CFU/g) of fresh and frozen-thawed pork loins during storage at $-1.5,4$, and $15^{\circ} \mathrm{C}$

\begin{tabular}{|c|c|c|c|c|c|c|c|c|}
\hline \multirow{2}{*}{ Microorganism } & \multirow{2}{*}{ Treatments } & \multirow{2}{*}{$\begin{array}{l}\text { Storage temperature } \\
\quad\left({ }^{\circ} \mathrm{C}\right)\end{array}$} & \multicolumn{6}{|c|}{ Storage period (day) } \\
\hline & & & 0 & 2 & 4 & 6 & 8 & 10 \\
\hline \multirow{6}{*}{ Total aerobic bacteria } & \multirow{3}{*}{$\begin{array}{l}\text { Control } \\
\text { (fresh) }\end{array}$} & 15 & $4.56 \pm 0.13^{1 \mathrm{Ac} 2)}$ & $7.40 \pm 0.15^{\mathrm{Ab}}$ & $9.10 \pm 0.07^{\mathrm{Aa}}$ & - & - & - \\
\hline & & 4 & $4.56 \pm 0.13^{\mathrm{Ae}}$ & $5.13 \pm 0.12^{\mathrm{Cd}}$ & $5.50 \pm 0.20^{\mathrm{Bc}}$ & $5.69 \pm 0.08^{\mathrm{Ac}}$ & $6.41 \pm 0.09^{\mathrm{Ab}}$ & $7.73 \pm 0.16^{\mathrm{Aa}}$ \\
\hline & & -1.5 & $4.56 \pm 0.13^{\mathrm{Ad}}$ & $4.73 \pm 0.14^{\mathrm{Dcd}}$ & $4.96 \pm 0.17^{\mathrm{Cc}}$ & $5.01 \pm 0.15^{\mathrm{Cbc}}$ & $5.28 \pm 0.22^{\mathrm{Bb}}$ & $5.62 \pm 0.10^{\mathrm{Ba}}$ \\
\hline & \multirow{3}{*}{$\begin{array}{l}\text { Frozen- } \\
\text { thawed }\end{array}$} & 15 & $4.02 \pm 0.11^{\mathrm{Bc}}$ & $6.50 \pm 0.12^{\mathrm{Bb}}$ & $9.30 \pm 0.07^{\mathrm{Aa}}$ & - & - & - \\
\hline & & 4 & $4.02 \pm 0.11^{\mathrm{Be}}$ & $4.20 \pm 0.21^{\mathrm{Ee}}$ & $4.68 \pm 0.16^{\mathrm{Dd}}$ & $5.35 \pm 0.18^{\mathrm{Bc}}$ & $6.24 \pm 0.12^{\mathrm{Ab}}$ & $7.70 \pm 0.10^{\mathrm{Aa}}$ \\
\hline & & -1.5 & $4.02 \pm 0.11^{\mathrm{Bb}}$ & $3.97 \pm 0.04^{\mathrm{Eb}}$ & $3.72 \pm 0.18^{\mathrm{Ec}}$ & $3.83 \pm 0.07^{\mathrm{Dbc}}$ & $3.84 \pm 0.16^{\mathrm{Cbc}}$ & $4.43 \pm 0.14^{\mathrm{Ca}}$ \\
\hline \multirow{6}{*}{ Coliform } & \multirow{3}{*}{$\begin{array}{l}\text { Control } \\
\text { (fresh) }\end{array}$} & 15 & $2.96 \pm 0.18^{\mathrm{Ac}}$ & $4.97 \pm 0.03^{\mathrm{Ab}}$ & $5.44 \pm 0.18^{\mathrm{Aa}}$ & - & - & - \\
\hline & & 4 & $2.96 \pm 0.18^{\mathrm{Ad}}$ & $3.32 \pm 0.20^{\mathrm{Cc}}$ & $3.28 \pm 0.15^{\mathrm{Cc}}$ & $3.38 \pm 0.17^{\mathrm{Ac}}$ & $3.71 \pm 0.15^{\mathrm{Ab}}$ & $4.24 \pm 0.13^{\mathrm{Aa}}$ \\
\hline & & -1.5 & $2.96 \pm 0.18^{\mathrm{Aa}}$ & $2.78 \pm 0.16^{\mathrm{Da}}$ & $2.89 \pm 0.16^{\mathrm{DEa}}$ & $2.64 \pm 0.18^{\mathrm{Aa}}$ & $2.86 \pm 0.16^{\mathrm{Ba}}$ & $2.77 \pm 0.14^{\mathrm{Ca}}$ \\
\hline & \multirow{3}{*}{$\begin{array}{l}\text { Frozen- } \\
\text { thawed }\end{array}$} & 15 & $2.85 \pm 0.14^{\mathrm{Ac}}$ & $4.29 \pm 0.05^{\mathrm{Bb}}$ & $4.94 \pm 0.12^{\mathrm{Ba}}$ & - & - & - \\
\hline & & 4 & $2.85 \pm 0.14^{\mathrm{Ab}}$ & $2.27 \pm 0.02^{\mathrm{Ec}}$ & $2.74 \pm 0.05^{\mathrm{Eb}}$ & $2.20 \pm 0.20^{\mathrm{Cc}}$ & $2.35 \pm 0.12^{\mathrm{Cc}}$ & $3.98 \pm 0.08^{\mathrm{Ba}}$ \\
\hline & & -1.5 & $2.85 \pm 0.14^{\mathrm{Aa}}$ & $2.84 \pm 0.09^{\mathrm{Da}}$ & $2.99 \pm 0.08^{\mathrm{Da}}$ & $2.37 \pm 0.09^{\mathrm{BCb}}$ & $1.99 \pm 0.18^{\mathrm{Dc}}$ & $1.07 \pm 0.12^{\mathrm{Dd}}$ \\
\hline \multirow{6}{*}{ Yeast and molds } & \multirow{3}{*}{$\begin{array}{l}\text { Control } \\
\text { (fresh) }\end{array}$} & 15 & $3.88 \pm 0.17^{\mathrm{Ac}}$ & $5.20 \pm 0.07^{\mathrm{Ab}}$ & $5.64 \pm 0.11^{\mathrm{Ba}}$ & - & - & - \\
\hline & & 4 & $3.88 \pm 0.17^{\mathrm{Ad}}$ & $3.84 \pm 0.07^{\mathrm{BCd}}$ & $3.97 \pm 0.09^{\mathrm{Cd}}$ & $4.63 \pm 0.01^{\mathrm{Ac}}$ & $5.34 \pm 0.12^{\mathrm{Ab}}$ & $5.85 \pm 0.09^{\mathrm{Aa}}$ \\
\hline & & -1.5 & $3.88 \pm 0.17^{\mathrm{Aa}}$ & $3.98 \pm 0.12^{\mathrm{Ba}}$ & $3.90 \pm 0.13^{\mathrm{Ca}}$ & $3.87 \pm 0.20^{\mathrm{Ba}}$ & $3.77 \pm 0.16^{\mathrm{Ba}}$ & $3.85 \pm 0.15^{\mathrm{Ca}}$ \\
\hline & \multirow{3}{*}{$\begin{array}{l}\text { Frozen- } \\
\text { thawed }\end{array}$} & 15 & $3.85 \pm 0.10^{\mathrm{Ac}}$ & $5.07 \pm 0.03^{\mathrm{Ab}}$ & $6.01 \pm 0.03^{\mathrm{Aa}}$ & - & - & - \\
\hline & & 4 & $3.85 \pm 0.10^{\mathrm{Ad}}$ & $3.97 \pm 0.10^{\mathrm{Bd}}$ & $3.85 \pm 0.05^{\mathrm{Cd}}$ & $4.44 \pm 0.16^{\mathrm{Ac}}$ & $5.28 \pm 0.09^{\mathrm{Ab}}$ & $5.89 \pm 0.15^{\mathrm{Aa}}$ \\
\hline & & -1.5 & $3.85 \pm 0.10^{\mathrm{Ab}}$ & $3.68 \pm 0.16^{\mathrm{Cb}}$ & $3.81 \pm 0.23^{\mathrm{Cb}}$ & $3.86 \pm 0.17^{\mathrm{Bb}}$ & $3.96 \pm 0.11^{\mathrm{Bab}}$ & $4.18 \pm 0.20^{\mathrm{Ba}}$ \\
\hline
\end{tabular}

\footnotetext{
${ }^{1)}$ Each value is mean $\pm \mathrm{SD}$
}

${ }^{2)}$ Mean values in the same column (A-E) or row (a-e) followed by different letters are significantly different according to Duncan's multiple range test $(\mathrm{p}<0.05)$. 
유발하여 소비자 기호도를 저하시키는 원인으로 작용한다 (39). 냉장육의 표면에 오염되어 있는 세균 수가 $7 \log \mathrm{CFU} / \mathrm{g}$ 수준에 도달하면 부패가 시작되고 8-9 $\log \mathrm{CFU} / \mathrm{g}$ 이상일 때 관능적으로 받아들일 수 없는 부패취가 감지되며 점질물 이 생성한다(40). 한편 $-1.5^{\circ} \mathrm{C}$ 저장 10 일 후 대조구와 냉동해동 처리구의 총 호기성 세균 수는 각각 5.62 와 $4.43 \mathrm{log}$ $\mathrm{CFU} / \mathrm{g}$ 으로 관찰되었다.

대조구와 냉동-해동 처리구의 대장균군 수는 각각 2.96 과 $2.85 \log \mathrm{CFU} / \mathrm{g}$ 으로 유의적인 차이를 보이지 않았다 (Table 4). $15^{\circ} \mathrm{C}$ 저장 4 일 후 대조구와 냉동-해동 처리구의
대장균군 수는 2.48 과 $2.09 \log \mathrm{CFU} / \mathrm{g}$ 증가하여 각각 5.44 와 $4.94 \log \mathrm{CFU} / \mathrm{g}$ 으로 측정되었다. 또한 $4^{\circ} \mathrm{C}$ 저장된 대조구와 냉동-해동 처리구의 경우도 대장균군 수가 저장 중 점차 증가하여 저장 10 일 후 4.24 와 $3.98 \log \mathrm{CFU} / \mathrm{g}$ 을 각각 나타 내었다. 반면 $-1.5^{\circ} \mathrm{C}$ 저장 중 대조구의 대장균군 수는 저장 초기 수준으로 유지하였으며 냉동-해동 처리구의 대장균군 수는 $1.07 \log \mathrm{CFU} / \mathrm{g}$ 까지 감소하였다.

효모 및 곰팡이의 경우에서도 대장균군과 유사한 결과를 나타냈는데, 저장 초기 냉동-해동 처리구의 효모 및 곰팡이 수는 $3.85 \log \mathrm{CFU} / \mathrm{g}$ 으로 대조구의 $3.88 \log \mathrm{CFU} / \mathrm{g}$ 과 비교

Table 5. Sensory evaluation of fresh and frozen-thawed pork loins during storage at $-1.5,4$, and $15^{\circ} \mathrm{C}$

\begin{tabular}{|c|c|c|c|c|c|c|c|c|}
\hline \multirow{2}{*}{$\begin{array}{l}\text { Organoleptic } \\
\text { parameter }\end{array}$} & \multirow{2}{*}{ Treatment } & \multirow{2}{*}{$\begin{array}{c}\text { Storage } \\
\text { temperature }\left({ }^{\circ} \mathrm{C}\right)\end{array}$} & \multicolumn{6}{|c|}{ Storage period (day) } \\
\hline & & & 0 & 2 & 4 & 6 & 8 & 10 \\
\hline \multirow{6}{*}{ Freshness } & \multirow{3}{*}{$\begin{array}{l}\text { Control } \\
\text { (fresh) }\end{array}$} & 15 & $8.90 \pm 1.22^{1 \mathrm{AA} 2)}$ & $3.20 \pm 1.03^{\mathrm{cb}}$ & $2.10 \pm 0.88^{\mathrm{Db}}$ & - & - & - \\
\hline & & 4 & $8.90 \pm 1.22^{\mathrm{Aa}}$ & $6.92 \pm 0.99^{\mathrm{Ab}}$ & $4.90 \pm 0.99^{\mathrm{Bc}}$ & $3.40 \pm 0.70^{\mathrm{Bcd}}$ & $2.54 \pm 0.71^{\mathrm{Bd}}$ & $2.24 \pm 0.97^{\mathrm{Bd}}$ \\
\hline & & -1.5 & $8.90 \pm 1.22^{\mathrm{Aa}}$ & $7.56 \pm 1.46^{\mathrm{Aab}}$ & $6.90 \pm 0.74^{\mathrm{Aab}}$ & $6.60 \pm 0.84^{\mathrm{Ab}}$ & $6.48 \pm 0.97^{\mathrm{Ab}}$ & $6.60 \pm 1.07^{\mathrm{Ab}}$ \\
\hline & \multirow{3}{*}{$\begin{array}{l}\text { Frozen- } \\
\text { thawed }\end{array}$} & 15 & $8.30 \pm 1.42^{\mathrm{Aa}}$ & $4.70 \pm 0.82^{\mathrm{BCb}}$ & $3.10 \pm 1.10^{\mathrm{CDb}}$ & - & - & - \\
\hline & & 4 & $8.30 \pm 1.42^{\mathrm{Aa}}$ & $6.40 \pm 1.07^{\mathrm{ABab}}$ & $4.40 \pm 1.07^{\mathrm{BCbc}}$ & $3.70 \pm 1.25^{\mathrm{Bcd}}$ & $2.20 \pm 0.63^{\mathrm{Bd}}$ & $2.10 \pm 1.37^{\mathrm{Bd}}$ \\
\hline & & -1.5 & $8.30 \pm 1.42^{\mathrm{Aa}}$ & $7.40 \pm 0.65^{\mathrm{Aab}}$ & $6.70 \pm 0.46^{\mathrm{Ab}}$ & $6.30 \pm 0.95^{\mathrm{Ab}}$ & $6.30 \pm 1.06^{\mathrm{Ab}}$ & $5.90 \pm 0.73^{\mathrm{Ab}}$ \\
\hline \multirow{6}{*}{ Appearance } & \multirow{3}{*}{$\begin{array}{l}\text { Control } \\
\text { (fresh) }\end{array}$} & 15 & $8.20 \pm 1.40^{\mathrm{Aa}}$ & $4.20 \pm 1.03^{\mathrm{Bb}}$ & $2.10 \pm 0.99^{\mathrm{Cb}}$ & - & - & - \\
\hline & & 4 & $8.20 \pm 1.40^{\mathrm{Aa}}$ & $6.70 \pm 1.06^{\mathrm{Aa}}$ & $4.70 \pm 0.95^{\mathrm{Bb}}$ & $3.40 \pm 0.97^{\mathrm{Bbc}}$ & $2.60 \pm 0.67^{\mathrm{Bc}}$ & $2.10 \pm 0.70^{\mathrm{Bc}}$ \\
\hline & & -1.5 & $8.20 \pm 1.40^{\mathrm{Aa}}$ & $7.10 \pm 1.00^{\mathrm{Aab}}$ & $7.10 \pm 0.74^{\mathrm{Aab}}$ & $6.40 \pm 0.91^{\mathrm{Aab}}$ & $6.70 \pm 0.65^{\text {Aab }}$ & $6.28 \pm 0.84^{\mathrm{Ab}}$ \\
\hline & \multirow{3}{*}{$\begin{array}{l}\text { Frozen- } \\
\text { thawed }\end{array}$} & 15 & $7.80 \pm 0.81^{\mathrm{Aa}}$ & $4.40 \pm 0.97^{\mathrm{Bb}}$ & $2.70 \pm 1.16^{\mathrm{cb}}$ & - & - & - \\
\hline & & 4 & $7.80 \pm 0.81^{\mathrm{Aa}}$ & $6.40 \pm 1.07^{\mathrm{Aab}}$ & $5.48 \pm 1.62^{\mathrm{ABb}}$ & $4.90 \pm 1.20^{\mathrm{ABb}}$ & $2.70 \pm 0.82^{\mathrm{Bc}}$ & $2.10 \pm 1.45^{\mathrm{Bc}}$ \\
\hline & & -1.5 & $7.80 \pm 0.81^{\mathrm{Aa}}$ & $7.30 \pm 0.79^{\mathrm{Aab}}$ & $6.40 \pm 1.07^{\mathrm{ABabc}}$ & $5.50 \pm 1.08^{\mathrm{Ac}}$ & $5.68 \pm 0.82^{\mathrm{Abc}}$ & $5.60 \pm 0.58^{\mathrm{Ac}}$ \\
\hline \multirow{6}{*}{ Texture } & \multirow{3}{*}{$\begin{array}{l}\text { Control } \\
\text { (fresh) }\end{array}$} & 15 & $7.30 \pm 0.58^{\mathrm{Aa}}$ & $5.12 \pm 1.15^{\mathrm{Bb}}$ & $3.10 \pm 1.10^{\mathrm{Cc}}$ & - & - & - \\
\hline & & 4 & $7.30 \pm 0.58^{\mathrm{Aa}}$ & $6.33 \pm 1.25^{\mathrm{ABab}}$ & $5.30 \pm 0.95^{\mathrm{Bb}}$ & $3.30 \pm 1.06^{\mathrm{Bc}}$ & $2.40 \pm 1.07^{\mathrm{Bc}}$ & $2.20 \pm 0.92^{\mathrm{Bc}}$ \\
\hline & & -1.5 & $7.30 \pm 0.58^{\mathrm{Aa}}$ & $7.50 \pm 0.65^{\mathrm{Aa}}$ & $6.93 \pm 0.42^{\mathrm{ABab}}$ & $6.30 \pm 0.88^{\mathrm{Aab}}$ & $6.40 \pm 0.62^{\mathrm{Aab}}$ & $5.98 \pm 0.77^{\mathrm{Ab}}$ \\
\hline & \multirow{3}{*}{$\begin{array}{l}\text { Frozen- } \\
\text { thawed }\end{array}$} & 15 & $8.07 \pm 0.82^{\mathrm{Aa}}$ & $6.00 \pm 1.41^{\mathrm{ABa}}$ & $3.20 \pm 1.03^{\mathrm{Cb}}$ & - & - & - \\
\hline & & 4 & $8.07 \pm 0.82^{\mathrm{Aa}}$ & $6.70 \pm 1.06^{\mathrm{ABab}}$ & $5.90 \pm 1.10^{\mathrm{ABb}}$ & $4.90 \pm 1.20^{\mathrm{ABb}}$ & $2.50 \pm 0.85^{\mathrm{Bc}}$ & $2.40 \pm 0.84^{\mathrm{Bc}}$ \\
\hline & & -1.5 & $8.07 \pm 0.82^{\mathrm{Aa}}$ & $7.30 \pm 1.02^{\mathrm{Aab}}$ & $7.10 \pm 0.79^{\mathrm{Aabc}}$ & $6.30 \pm 1.06^{\mathrm{Abc}}$ & $6.10 \pm 0.45^{\mathrm{Abc}}$ & $5.60 \pm 0.71^{\mathrm{Ac}}$ \\
\hline \multirow{6}{*}{ Odor } & \multirow{3}{*}{$\begin{array}{l}\text { Control } \\
\text { (fresh) }\end{array}$} & 15 & $8.60 \pm 1.35^{\mathrm{Aa}}$ & $4.70 \pm 1.64^{\mathrm{Bb}}$ & $1.80 \pm 0.87^{\mathrm{Cc}}$ & - & - & - \\
\hline & & 4 & $8.60 \pm 1.35^{\mathrm{Aa}}$ & $7.55 \pm 1.25^{\mathrm{Aa}}$ & $4.10 \pm 0.99^{\mathrm{BCb}}$ & $3.00 \pm 1.15^{\mathrm{Bbc}}$ & $1.50 \pm 0.71^{\mathrm{Bc}}$ & $1.40 \pm 0.84^{\mathrm{Bc}}$ \\
\hline & & -1.5 & $8.60 \pm 1.35^{\mathrm{Aa}}$ & $8.30 \pm 1.64^{\mathrm{Aab}}$ & $7.20 \pm 1.23^{\mathrm{Aabc}}$ & $5.92 \pm 0.88^{\mathrm{Abc}}$ & $5.27 \pm 1.40^{\mathrm{Ac}}$ & $4.80 \pm 1.32^{\mathrm{Ac}}$ \\
\hline & \multirow{3}{*}{$\begin{array}{l}\text { Frozen- } \\
\text { thawed }\end{array}$} & 15 & $8.60 \pm 1.06^{\mathrm{Aa}}$ & $4.50 \pm 1.18^{\mathrm{Bb}}$ & $2.20 \pm 1.75^{\mathrm{Cb}}$ & - & - & - \\
\hline & & 4 & $8.60 \pm 1.06^{\mathrm{Aa}}$ & $7.50 \pm 1.27^{\mathrm{Aa}}$ & $4.80 \pm 1.32^{\mathrm{ABb}}$ & $4.50 \pm 1.18^{\mathrm{ABbc}}$ & $2.50 \pm 1.08^{\mathrm{Bcd}}$ & $1.70 \pm 0.82^{\mathrm{Bd}}$ \\
\hline & & -1.5 & $8.60 \pm 1.06^{\mathrm{Aa}}$ & $7.60 \pm 1.96^{\mathrm{Aab}}$ & $6.62 \pm 1.58^{\mathrm{Aabc}}$ & $5.46 \pm 1.26^{\mathrm{Abc}}$ & $4.90 \pm 0.99^{\mathrm{Ac}}$ & $4.20 \pm 0.92^{\mathrm{Ac}}$ \\
\hline \multirow{6}{*}{$\begin{array}{c}\text { Overall } \\
\text { acceptability }\end{array}$} & \multirow{3}{*}{$\begin{array}{l}\text { Control } \\
\text { (fresh) }\end{array}$} & 15 & $8.80 \pm 1.45^{\mathrm{Aa}}$ & $3.00 \pm 0.94^{\mathrm{Bb}}$ & $1.90 \pm 0.99^{\mathrm{Bb}}$ & - & - & - \\
\hline & & 4 & $8.80 \pm 1.45^{\mathrm{Aa}}$ & $8.63 \pm 1.25^{\mathrm{Aab}}$ & $6.92 \pm 0.74^{\mathrm{Abc}}$ & $6.40 \pm 0.88^{\mathrm{Acd}}$ & $4.88 \pm 0.84^{\text {Bde }}$ & $3.56 \pm 0.67^{\mathrm{Be}}$ \\
\hline & & -1.5 & $8.80 \pm 1.45^{\mathrm{Aa}}$ & $8.40 \pm 1.27^{\mathrm{Aab}}$ & $8.02 \pm 0.67^{\mathrm{Aab}}$ & $7.20 \pm 0.99^{\mathrm{Aab}}$ & $6.80 \pm 0.84^{\mathrm{Aab}}$ & $6.24 \pm 1.40^{A b}$ \\
\hline & \multirow{3}{*}{$\begin{array}{l}\text { Frozen- } \\
\text { thawed }\end{array}$} & 15 & $8.60 \pm 0.78^{\mathrm{Aa}}$ & $4.40 \pm 1.17^{\mathrm{Bb}}$ & $2.10 \pm 0.88^{\mathrm{Bb}}$ & - & - & - \\
\hline & & 4 & $8.60 \pm 0.78^{\mathrm{Aa}}$ & $7.80 \pm 1.23^{\mathrm{Aab}}$ & $6.60 \pm 1.07^{\mathrm{Aabc}}$ & $5.82 \pm 1.07^{\mathrm{Abc}}$ & $5.10 \pm 0.74^{\mathrm{Bcd}}$ & $3.22 \pm 1.26^{\mathrm{Bd}}$ \\
\hline & & -1.5 & $8.60 \pm 0.78^{\mathrm{Aa}}$ & $8.26 \pm 1.14^{\mathrm{Aab}}$ & $8.16 \pm 1.66^{\mathrm{Aab}}$ & $6.82 \pm 0.92^{\mathrm{Aab}}$ & $6.24 \pm 0.92^{\mathrm{ABab}}$ & $5.87 \pm 1.32^{\mathrm{Ab}}$ \\
\hline
\end{tabular}

${ }^{1)}$ Each value is mean $\pm \mathrm{SD}$.

${ }^{2)}$ Mean values in the same column (A-D) or row (a-e) followed by different letters are significantly different according to Duncan's multiple range test $(\mathrm{p}<0.05)$. 
하여 유의적 차이를 보이지 않았다(p<0.05). $4^{\circ} \mathrm{C}$ 저장된 대 조구와 냉동-해동 처리구의 효모 및 곰팡이 수는 저장 중 점차 증가하여 저장 10 일 후 각각 5.85 와 $5.89 \log \mathrm{CFU} / \mathrm{g}$ 을 나타냈다. 반면 $-1.5^{\circ} \mathrm{C}$ 저장에서 대조구와 냉동-해동 처리구 의 효모 및 곰팡이 수는 저장 초기 수준을 유지하였다. 일반 적으로 육류의 냉동 저장은 호냉성 세균을 제외한 대부분 미생물 생육을 억제시켜 신선도를 유지하지만 동결로 인한 물성변화, 육표면 탈수 및 향미 변화가 수반된다(2). 반면 본 연구에서 $-1.5^{\circ} \mathrm{C}$ 과냉각 저장은 돈육 조직에 얼음결정 형성 없이 저장 중 돈육에 오염된 미생물 수 증가를 효과적 으로 억제할 수 있음을 확인하였다. 냉동육의 위생관리를 위해 해동 직후 가공에 이용하거나 과냉각 저장하는 것이 바람직 할 것으로 생각된다.

\section{저장 중 관능적 품질 변화}

냉동 및 해동 처리된 돈육의 저장 중 관능평가 결과는 Table 5에 나타내었다. 저장 초기 냉동-해동 처리구는 대조 구와 비교 시, 신선도, 외관, 조직감, 냄새와 전체적인 기호 도 측면에서 유의적인 차이가 없는 것으로 나타났다 $(\mathrm{p}<0.05) .15^{\circ} \mathrm{C}$ 저장 4 일 후 대조구와 냉동-해동 처리구는 관능평가 항목 중 신선도, 외관, 냄새, 전체적인 기호도에서 3점 이하를 나타냈으며 돈육 시료의 표면에 점액질 분비가 일어나고 부패취가 발생하였다. 한편 $4^{\circ} \mathrm{C}$ 저장 10 일 후 대조 구와 냉동-해동 처리구의 전체적인 기호도는 각각 3.56 과 3.22 점으로 감소하였지만 $-1.5^{\circ} \mathrm{C}$ 저장한 대조구와 냉동-해 동 처리구의 전체적인 기호도는 각각 6.24와 5.87점으로 유의적으로 높은 값을 유지하였다(p<0.05). Shin 등(41)은 돈육과 우육을 $2^{\circ} \mathrm{C}$ 저온저장에서 10 일간 저장하며 관능평 가를 실시한 결과 저장 6-8일 후 부패취 발생으로 가식이 불가능하다고 보고하였는데 본 연구결과와 유사하였다.

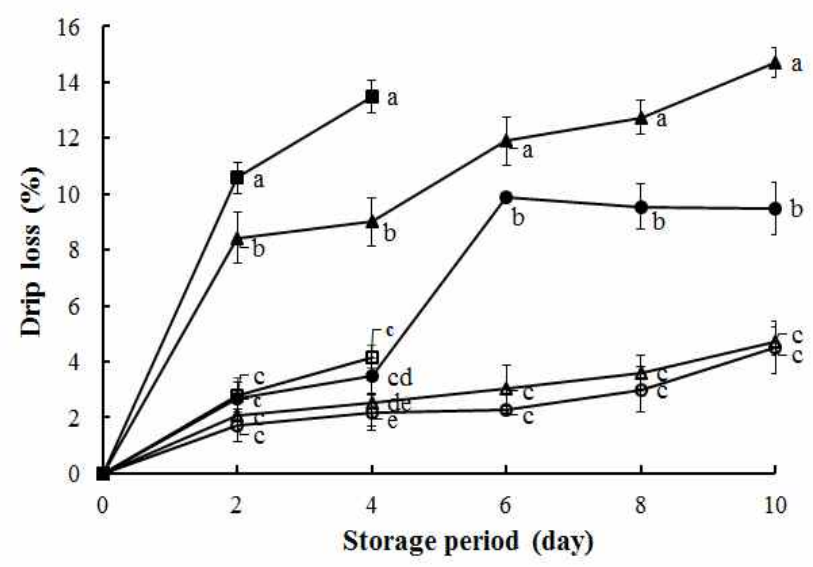

Fig. 4. Changes in the weight loss of fresh and frozen-thawed pork loins during storage at $-1.5,4$, and $15^{\circ} \mathrm{C}$.

$\square$, control $\left(15^{\circ} \mathrm{C}\right) ; \triangle$, control $\left(4^{\circ} \mathrm{C}\right) ; \mathrm{O}$, control $\left(-1.5^{\circ} \mathrm{C}\right)$;

Frozen-thawed;

control $\left(4^{\circ} \mathrm{C}\right)$;, control $\left(-1.5^{\circ} \mathrm{C}\right)$.

Means with different letters differ significantly $(\mathrm{p}<0.05)$ within the same storage day.
Stonehouse 등(17)은 2 와 $5^{\circ} \mathrm{C}$ 에 저장된 돈육과 비교하여 $-1.5^{\circ} \mathrm{C}$ 에 저장된 돈육에서 유의적으로 이취가 적게 나타났 으며 저장 28 일 동안 폐기되는 샘플의 수가 더 적었다고 보고하였다. 이러한 결과를 통해 과냉각 저장이 기존 냉장 저장에 비해 돈육의 관능적 품질 유지 측면에서 바람직하다 고 판단된다.

\section{요 약}

본 연구는 초저온 액체 침지식 급속 냉동으로 동결된 돈육 등심에 적합한 급속 해동방법을 선정하고 과냉각 저장 이 냉동-해동 돈육의 미생물학적, 이화학적 및 관능적 품질 변화에 미치는 영향을 살펴보았다. 4 와 $10^{\circ} \mathrm{C}$ 송풍식 해동과 4 와 $10^{\circ} \mathrm{C}$ 유수식 해동은 냉동 돈육 시료가 해동이 완료되는 약 290-750분 소요되었지만 $27.12 \mathrm{MHz}$ 라디오파 해동은 약 20 분으로 가장 신속하게 돈육을 해동시켜 저장실험에 필요한 냉동 돈육의 급속 해동방법으로 선정하였다. 한편 $-1.5-5^{\circ} \mathrm{C}$ 로 24 시간 냉각 처리 후 돈육 횡단면의 미세구조 분석 결과, $-1.5^{\circ} \mathrm{C}$ 에서 냉각 처리된 시료의 표면과 중심부는 동결에 의한 조직 손상이 발생하지 않았음을 확인하여 -1 . $5^{\circ} \mathrm{C}$ 를 과냉각 저장 온도로 선정하였다. 저장 중 대조구인 신선육과 비교하여 냉동-해동 처리된 돈육에서 발생한 드 립감량은 유의적으로 $(\mathrm{p}<0.05)$ 높은 경향을 보였지만 $-1.5^{\circ} \mathrm{C}$ 과냉각 저장이 돈육의 드립감량 증가를 억제하였다. 또한 4 와 $15^{\circ} \mathrm{C}$ 저장과 비교하여 $-1.5^{\circ} \mathrm{C}$ 과냉각 저장은 대조구와 냉동-해동 처리구의 TVBN과 TBARS 함량 증가, Hunter $\mathrm{a}^{*}$ 값 감소와 $\mathrm{b}^{*}$ 값 증가를 억제하는 효과를 보였다. $15^{\circ} \mathrm{C}$ 저장 4일 후 대조구와 냉동-해동 처리구의 총 호기성 세균 수는 $9 \log \mathrm{CFU} / \mathrm{g}$ 이상으로 급격히 증가하였다. 반면 $-1.5^{\circ} \mathrm{C}$ 저장 10 일 후 대조구와 냉동-해동 처리구의 총 호기성 세균 수는 각각 5.62 와 $4.43 \log \mathrm{CFU} / \mathrm{g}$ 으로 관찰되었다. $-1.5^{\circ} \mathrm{C}$ 저장 10 일 동안 대조구와 냉동-해동 처리구의 대장균군과 효모 및 곰팡이 수는 저장 초기 수준으로 유지하거나 다소 감소하였다. 관능평가 결과에 있어서 4 와 $15^{\circ} \mathrm{C}$ 저장에 비해 $-1.5^{\circ} \mathrm{C}$ 저장한 대조구와 냉동-해동 처리구는 모든 관능평가 항목에서 저장 중 유의적으로 높은 값을 유지하였다 (p<0.05). 따라서 라디오파 유전가열 해동은 냉동 돈육 등심 의 해동 과정 중 상전이 구간을 빠르게 통과함으로써 급속 해동이 가능하였으며 $-1.5^{\circ} \mathrm{C}$ 과냉각 저장이 냉동-해동 처리 된 돈육에 얼음결정 형성 없이 품질 유지 및 미생물 생장 지연에 효과적인 것을 확인하였다.

\section{감사의 글}

본 연구는 2017년 농촌진흥청 공동연구사업(과제번호: 
PJ0108362017)의 지원에 의해 이루어진 것으로 감사드립 니다.

\section{References}

1. Seong PM, Cho SH, Kim JH, Hah KH, Park BY, Lee JM, Kim DH (2009) Meat quality of pork muscles from low-fat cuts. Korean J Food Sci Ani Resour, 29, 364-373

2. Moon YH (2013) Changes in physical properties of ham and loin from low-fat pork cuts during chilling after thawing. J East Asian Soc Dietary Life, 23, 487-495

3. Park MH, Kwon JE, Kim SR, Won JH, Ji JY, Hwang IK, Kim MR (2012) Physicochemical and microbiological properties of pork by various thawing methods. J East Asian Soc Dietary Life, 22, 298-304

4. Tak SB, Kim DH, Yoon SK, Lee YC (2005) Effects of natural preservatives and storage temperatures on quality and shelf-life of fresh pork meat. Korean J Food Sci Technol, 37, 557-561

5. Jeong JY, Yang HS, Kang GH, Lee JI, Park GB, Joo ST (2006) Effect of freeze-thaw process on myoglobin oxidation of pork loin during cold storage. Korean J Food Sci Ani Resour, 26, 1-8

6. Li B, Sun DW (2002) Novel methods for rapid freezing and thawing of foods-a review. J Food Eng, 54, 175-182

7. Liang D, Lin F, Yang G, Yue X, Zhang Q, Zhang Z, Chen $H$ (2015) Advantages of immersion freezing for quality preservation of litchi fruit during frozen storage. LWT-Food Sci Technol, 60, 948-956

8. Yun CG, Lee DH, Park JY (1998) Ohmic thawing of a frozen meat chunk. Korean J Food Sci Technol, 30, 842-847

9. Lee JK, Park JY (1999) Rapid thawing of frozen pork by $915 \mathrm{MHz}$ microwave. Korean J Food Sci Technol, 31, 54-61

10. Beauchamp CS, Byelashov OA, Geornaras I, Kendall PA, Scanga JA, Belk KE, Smith GC, Sofos JN (2010) Fate of Listeria monocytogenes during freezing, thawing and home storage of frankfurters. Food Microbiol, 27, 144-149

11. Leygonie C, Britz TJ, Hoffman LC (2012) Impact of freezing and thawing on the quality of meat: Review. Meat Sci, 91, 93-98

12. Awuah GB, Ramaswamy HS, Economides A, Mallikarjunan $\mathrm{K}$ (2005) Inactivation of Escherichia coli K-12 and Listeria innocua in milk using radio frequency $(\mathrm{RF})$ heating. Innov Food Sci Emerg Technol, 6, 396-402

13. Farag KW, Lyng JG, Morgan DJ, Cronin DA (2011) A comparison of conventional and radio frequency thawing of beef meats: Effects on product temperature distribution. Food Bioprocess Tech, 4, 1128-1136

14. Akgul NB, Basaran P, Rasco BA (2008) Effect of temperature $\left(-5\right.$ to $\left.130^{\circ} \mathrm{C}\right)$ and fiber direction on the dielectric properties of beef semitendinosus at radio frequency and microwave frequencies. J Food Sci, 73, 243-249

15. Choi MS, Choi JA, Kim MH, Park GJ (2011) The comparison and distribution of temperatures established in display stands and food surfaces for cold and frozen foods in large discount stores in Korea. J Fd Hyg Saf, 26, 308-314

16. Choi EJ, Kim MH, Bahk GJ (2011) Sanitary conditions for cold and frozen food storage warehouses in Korea. J Fd Hyg Saf, 26, 283-288

17. Stonehouse GG, Evans JA (2015) The use of supercooling for fresh foods: A review. J Food Eng, 148, 74-79

18. Mok JH, Her JY, Kang TY, Hoptowit R, Jun SJ (2017) Effects of pulsed electric field (PEF) and oscillating magnetic field (OMF) combination technology on the extension of supercooling for chicken breasts. J Food Eng, 196, 27-35

19. Fukuma Y, Yamane A, Itoh T, Tsukamasa Y, Ando M (2011) Application of supercooling to long-term storage of fish meat. Fish Sci, 78, 451-461

20. Song BS, Park JG, Kim WG, Kim JH, Choi JI, Yoon YH, Byun MW, Kim CJ, Lee JW (2009) Comparison of the quality of gamma ray- or electron beam-irradiated minced pork and pork patties. Korean J Food Sci Ani Resour, 29, 194-202

21. Gil J, Kim DW, Kim HJ, Yoon JY, Pak JI, Park BY, Ham JS, Jang A (2015) Changes of meat quality and antioxidation activity in the loin and ham of Korean Native Black Pigs during frozen storage. J Life Sci, 25, 740-747

22. Kim YB, Woo SM, Jeong JY, Ku SK, Jeong JW, Kum JS, Kim EM (2013) Temperature changes during freezing and effect of physicochemical properties after thawing on meat by air blast and magnetic resonance quick freezing. Korean J Food Sci An, 33, 763-771

23. Kim E, Choi DY, Kim HC, Kim K, Lee SJ (2013) Calibrations between the variables of microbial TTI response and ground pork qualities. Meat Sci, 95, 362-367

24. Nam KC, Ahn DU (2002) Carbon monoxide-heme 
pigment is responsible for the pink color in irradiated raw turkey breast meat. Meat Sci, 60, 25-33

25. He X, Liu R, Nirasawa S, Zheng D, Liu H (2013) Effect of high voltage electrostatic field treatment on thawing characteristics and post-thawing quality of frozen pork tenderloin meat. J Food Eng, 115, 245-250

26. Uyar R, Bedane TF, Erdogdu F, Palazoglu TK, Farag KW, Marra F (2015) Radio-frequency thawing of food products-A computational study. J Food Eng, 146, 163-171

27. Llave Y, Terada Y, Fukuoka M, Sakai N (2014) Dielectric properties of frozen tuna and analysis of defrosting using a radio-frequency system at low frequencies. J Food Eng, 139, 1-9

28. Jeremiah LE, Gibson LL (2001) The influence of storage temperature and storage time on color stability, retail properties and case-life of retail-ready beef. Food Res Int, 34, 815-826

29. Moon YH (2008) Effects of feeding citrus byproducts on pork quality during cold storage. J East Asian Soc Dietary Life, 18, 633-640

30. Warner RD, Kauffman R G, Greaser ML (1997) Muscle protein changes post mortem in relation to pork quality traits. Meat Sci, 45, 339-352

31. Bee G, Anderson AL, Lonergan SM, Huff-Lonergan E (2007) Rate and extent of $\mathrm{pH}$ decline affect proteolysis of cytoskeletal proteins and water-holding capacity in pork. Meat Sci, 76, 359-365

32. Ko MS, Yang JB (2001) Effects of wrap and vacuum packaging on shelf life of chilled pork. Korean J Food Nutr, 14, 255-262

33. Zhou GH, Xu XL, Liu Y (2010) Preservation technologies for fresh meat-A review. Meat Sci, 86, 119-128
34. Lee JI, Lee JD, Ha YJ, Jung JD, Lee JW, Lee JR, Kwack SC, Kim DH, Do CH (2005) Effects of dietary silkworm droppings on quality characeristics of pork loin. Korea J Food Sci Ani Resour, 25, 175-188

35. Guo M, Jin TZ, Yang R, Antenucci R, Mills B, Cassidy J, Scullen OJ, Sites JE, Rajkowski KT, Sommers CH (2013) Inactivation of natural microflora and inoculated Listeria innocua on whole raw shrimp by ozonated water, antimicrobial coatings, and cryogenic freezing. Food Control, 34, 24-30

36. Haughton PN, Lyng J, Cronin D, Fanning S, Whyte P (2012) Effect of crust freezing applied alone and in combination with ultraviolet light on the survival of Campylobacter on raw chicken. Food Microbiol, 32, 147-151

37. Choi EJ, Chung YB, Kim JS, Chun HH (2016) Effects of freezing and thawing treatments on natural microflora, inoculated Listeria monocytogenes and Campylobacter jejuni on chicken breast. J Food Hyg Saf, 31, 42-50

38. Nauta M, Hill A, Rosenquist H, Brynestad S, Fetsch A, van der Logt P, Fazil A, Christensen B, Katsma E, Borck B, Havelaar A (2009) A comparison of risk assessments on Campylobacter in broiler meat. Int J Food Microbiol, 129, 107-123

39. Kim SK, Lee MS, Lee KT, Park SK, Song KB (2004) Changes in quality of pork and beef during storage and electronic nose analysis. Korean J Food Preserv, 11, 441-447

40. Laack RLJM (1994) Spoilage and preservation of muscle foods. In: Muscle Foods, Springer US, New York, NY, USA, p 378-405

41. Shin HY, Ku KJ, Park SK, Song KB (2006) Use of freshness indicator for determination of freshness and quality change of beef and pork during storage. Korean J Food Sci Technol, 38, 325-330 